\title{
Social Values and Solar Energy Policy: The Policy Maker and the Advocate
}

Avraham Shama

Ken Jacobs
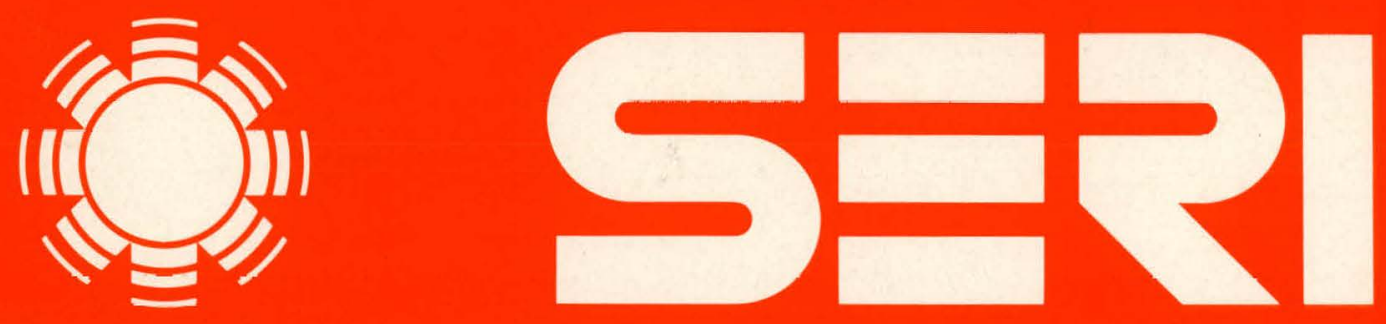

Solar Energy Research Institute

A Division of Midwest Research Institute

1617 Cole Boulevard

Golden, Colorado 80401

Operated for the

U.S. Department of Energy

under Contract No. EG-77-C-01-4042 


\section{DISCLAIMER}

This report was prepared as an account of work sponsored by an agency of the United States Government. Neither the United States Government nor any agency Thereof, nor any of their employees, makes any warranty, express or implied, or assumes any legal liability or responsibility for the accuracy, completeness, or usefulness of any information, apparatus, product, or process disclosed, or represents that its use would not infringe privately owned rights. Reference herein to any specific commercial product, process, or service by trade name, trademark, manufacturer, or otherwise does not necessarily constitute or imply its endorsement, recommendation, or favoring by the United States Government or any agency thereof. The views and opinions of authors expressed herein do not necessarily state or reflect those of the United States Government or any agency thereof. 


\section{DISCLAIMER}

Portions of this document may be illegible in electronic image products. Images are produced from the best available original document. 


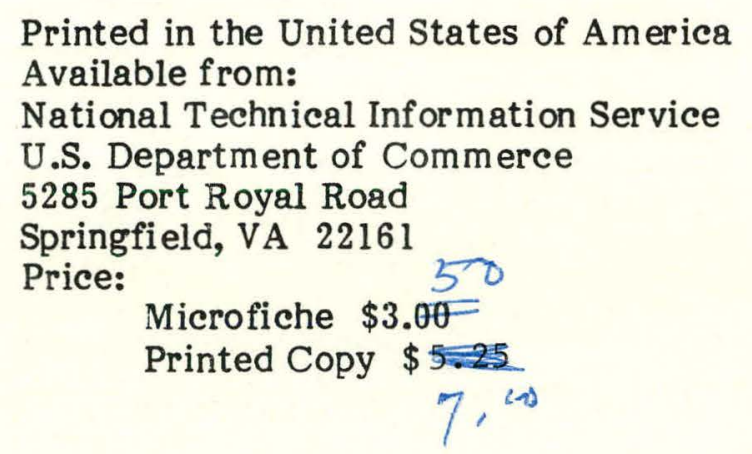

\section{NOTICE}

This report was prepared as an account of work sponsored by the United States Government. Neither the United States nor the United States Department of Energy, nor any of their employees, nor any of their contractors, subcontractors, or their employees, makes any warranty, express or implied, or assumes any legal liability or responsibility for the accuracy, completeness or usefulness of any information, apparatus, product or process disclosed, or represents that its use would not infringe privately owned rights. 
SOCIAL VALUES AND SOLAR ENERGY POLICY: THE POLICY MAKER AND THE ADVOCATE

AVRAHAM SHAMA

KEN JACOBS

JULY 1980

PREPARED UNDER TASK NO. 5326.40

\section{Solar Energy Research Institute}

A.Division of Midwest Research Institute

1617 Cole Boulevard

Golden, Colorado 80401

Prepared for the

U.S. Department of Energy

Contract No. EG-77-C-01-4042 
THIS PAGE

\section{WAS INTENTIONALLY \\ LEFT BLANK}




\section{PREFACR}

This research report documents work performed under "Social Values and Solar Energy Policy," subtask 5326.40. The study is a systematic investigation of the values that underlie judgments made about solar energy. It focuses on differences in values that policy makers and solar advocates associate with solar energy. As such, it may serve as a working guide for researchers and policy makers interested in social values and solar energy policy.
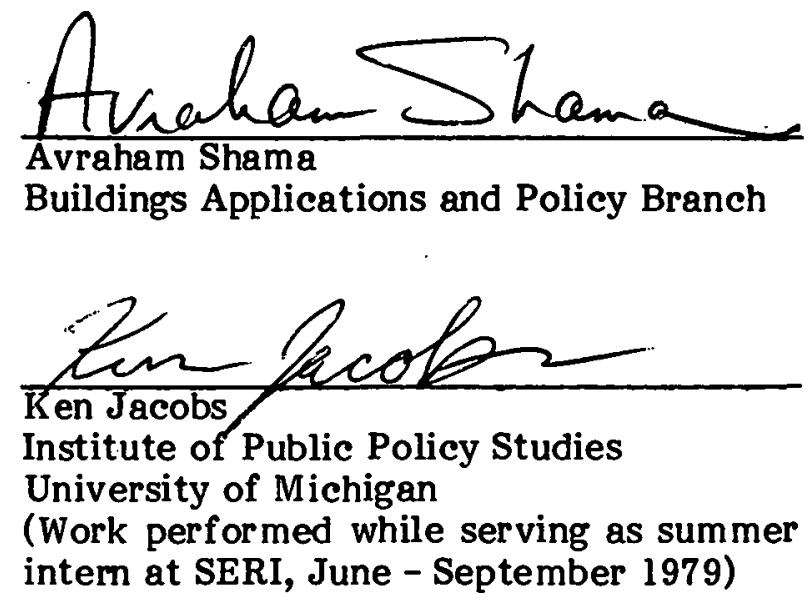

$\Lambda$ pproved for:

SOLAR ENERGY RESEARCH INSTITUTE

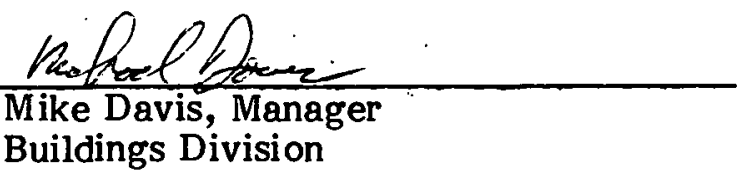




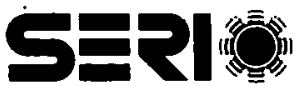


SUMMARY

\section{OBJECTIVES}

Two key groups of actors in the solar energy policy-making arena include: (1) those responsible for designing, implementing, and evaluating solar energy policies; and (2) those outside the government who play an active role in undertaking or promoting a more rapid adoption of solar energy. These groups are identified as "policy makers" and "advocates" in the present study.

The different policy orientations of the two groups seem to be the outcome of the values they hold and the weights they assign to different types of values. The ongoing national energy dilemma indicates that new choices of values regarding solar energy policy may prove useful. This study helps shed light upon two such options.

\section{METHODS}

Content analysis of public pronouncements by policy makers and advocates was used to achieve the following objectives: identify, define, cluster, and rank-order the values that policy makers and advocates associate with solar energy policy. The first of these objectives was met by extracting and recording each mention or implication of a value in the data. From the list of values that emerged for each group, a small number of value clusters (i:e., economic, social, environmental, security, and ethical) was defined in such a way as to maximize the comparability of the two data sets, while maintaining the accuracy of the views expressed in the literature.

Two separate methods were used simultaneously to rank-order, or otherwise discern, the hierarchy among the values of the two groups. First, the proportionate frequency with which each source mentioned or implied each value cluster was identified, then averaged within the larger group. Higher frequency of mention was taken to indicate a greater weight for that value cluster. Second, qualitative analysis was undertaken to discern the full argument regarding the value hierarchy that many of the sources contained.

\section{CONCLUSIONS}

- Policy makers attach greater weight to economic values (accounting for $52 \%$ of all their value mentions) which they define along traditional lines of "cost effeotiveness." However, they alsn frequently mention environmental, security, and social values (17\%,16\%, and $13 \%$, respectively). Environmental values generally are defined by policy makers as pertaining to pollution reduction and to health and safety enhancement. Social values may refer to solar energy as a means to either avoid or enhance social change. Security is more often cited as pertaining to national rather than community or personal security. Ethical values are discussed rarely by policy makers (1\%). The findings via frequency analysis were confirmed largely by the qualitative analysis. Policy makers tend to view economic values not only as ends in themselves (i.e., terminal values), but also as means (i.e., instrumental values) to achieve all other values. Thus, policy makers appear to be comfortable with placing all values in an economicully quantitative form. 
- Advocates distribute the weight among the different value clusters more equally than do policy makers and they also apply broader definitions to these clusters. Economic values receive $33 \%$ of their value mentions. Advocates not only define economic value with reference to efficiency, but also give attention to equity and long-term sustainability. Additionally, unlike policy makers, advocates do not necessarily value economic growth. Advocates give nearly equal weight to social values and to economic values (32\%). They tend to view solar energy as an avenue to social decentralization. Holism describes the environmental value (24\%) of advocates; i.e., people must live in harmony with nature. Pragmatic manifestations pertaining to pollution, health, and safety are included also. Ethical values (7\%) pertain to advocates' beliefs that adoption of decentralized solar technologies will lead to greater personal choice, freedom, and growth; hence, cultural and spiritual development as well. Security values (4\%) generally pertain to personal and community security afforded by decentralized solar adoption.

- Frequency analysis, however, does not give a complete picture of the advocates' values. Advocates of ten describe their values in a way that indicates the lngical precedence of environmental considerations (e.g., limitedness) and humanisticethical values over the other value clusters. Economic and, to a lesser extent, social values are treated mainly as instruments for the attainment of these higher-order terminal values. For policy makers, on the other hand, the discipline of economics appears to he a mmiel within which they wish to conccive all other values.

- The findings from this study may be useful to solar energy policy researchers and policy makers. To policy researchers, the findings may be useful because they constitute a guide to social values that policy makers associate with solar energy. An example of research using social values as variables in its econometric model is the Strategic Planning Project of the Solar Energy Research Institute. Among other variables, the project uses social values associated with various solar technologies in order to rank-order such technologies acenrding to their expected benefits to society. In the past, the project has assigned equal weights to all values but, in view of the findings of the present study, the above practice may have to be changed. To solar energy policy makers as a group, the findings may help clarify the social values that their policies may help bring about or reinforce. 


\section{TABLE OF CONTENTS}

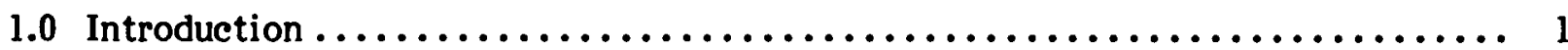

1.1 Objectives $\ldots \ldots \ldots \ldots \ldots \ldots \ldots \ldots \ldots \ldots \ldots \ldots \ldots \ldots \ldots \ldots \ldots \ldots \ldots \ldots \ldots \ldots \ldots$ 1

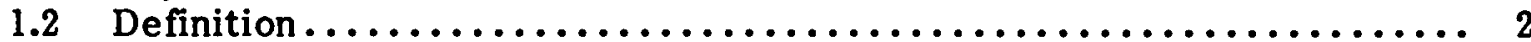

1.2.1 Public Policy Makers .............................. 2

1.2 .2 Advocates.................................. 2

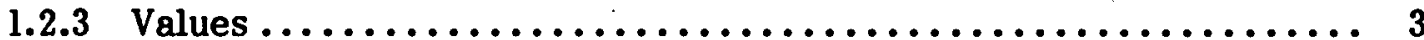

1.2.4 Terminal versus Instrum ental Values $\ldots \ldots \ldots \ldots \ldots \ldots \ldots \ldots \ldots \ldots \ldots \ldots 3$

1.2 .5 Value System ................................ 4

1.2.6 Values and Public Policy $\ldots \ldots \ldots \ldots \ldots \ldots \ldots \ldots \ldots \ldots \ldots \ldots \ldots \ldots$

2.0 Methodology and Procedure............................. 7

3.0 Findings $\ldots \ldots \ldots \ldots \ldots \ldots \ldots \ldots \ldots \ldots \ldots \ldots \ldots \ldots \ldots \ldots \ldots \ldots \ldots \ldots \ldots \ldots$

3.1 Policy Makers: Value Clusters ......................... 11

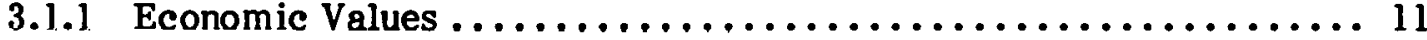

3.1.2 Environmental Values ............................ 11

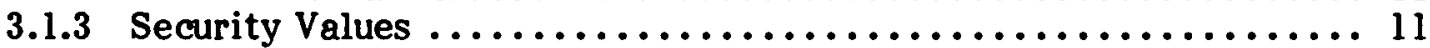

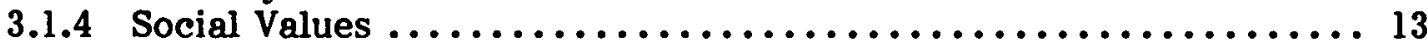

3.1.5 Ethical Values ............................... 13

3.2 Policy Makers: Rank-Ordering of Value Clusters ................. 13

3.3 Advocates: Value Clusters ............................ 15

3.3.1 Social Values .................................. 15

3.3.1.1 Meaningful Choice through Decentralization .......... 15

3.3.1.2 Directing Sociopolitical Trends and Priorities .......... 15

3.3 .2 Economic Values .............................. 17

3.3.2.1 Economic Holism......................... 17

3.3.2.2 Efficiency........................... 17

3.3.2.3 Equity ............................. 18

3.3.2.4 Stability versus Sustainability $\ldots \ldots \ldots \ldots \ldots \ldots \ldots \ldots \ldots \ldots 18$

3.3.2.5 Growth versus Sufficiency ..................... 18

3.3.3 Environmental Values ........................... 18

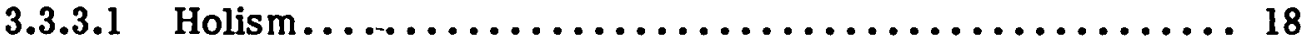

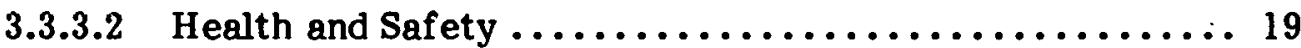

3.3.3.3 Limits ................................. 19

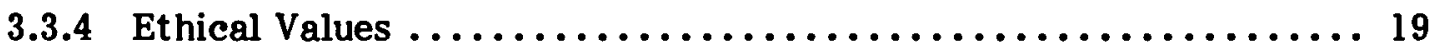

3.3.5 Community and National Security $\ldots \ldots \ldots \ldots \ldots \ldots \ldots \ldots \ldots \ldots$

3.4 Advocates: Rank-Ordering of Value Clusters $\ldots \ldots \ldots \ldots \ldots \ldots \ldots \ldots \ldots$

4.0 Comparison of the Values of Policy Makers and Advocates ............. 23

$4.1 \quad$ Relative Emphasis................................. 23

4.1.1 Economic Values ................................ 23

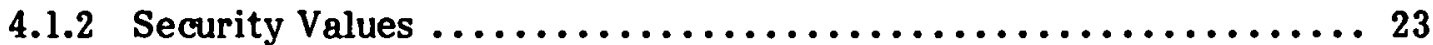

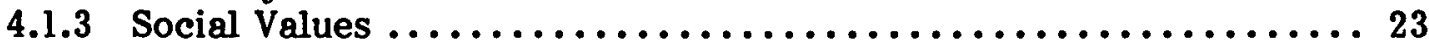

4.1.4 Environmental Values ............................ 23

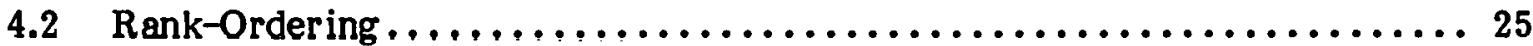

4.3 Qualitative Differences ............................... 25 
TABLE OP CONTBNTS (concluded)

Page

5.0 Conclusion $\ldots \ldots \ldots \ldots \ldots \ldots \ldots \ldots \ldots \ldots \ldots \ldots \ldots \ldots \ldots \ldots \ldots \ldots \ldots, 27$

6.0 References........................................... 29

Appendix A Values Mentioned or Implied by the Individual

Policy Makers and Advocates ......................... 31

Appendix B Social Values Taxonomy of Solar Energy: Policy Makers.........43

Appendix C Social Values Taxonomy of Solar Energy: Advocates ........... 45

Appendix D The Proportionate Frequency with Which Policy Makers and Advocates Attribute Various Values to Solar Energy $. . \ldots \ldots \ldots \ldots \ldots \ldots \ldots \ldots \ldots \ldots \ldots \ldots \ldots, 49$

Appendix E The Value Hierarnhies of Snme Advnnates $\ldots \ldots \ldots \ldots \ldots \ldots \ldots .53$

Appendix F Bibliography: Policy Makers $\ldots \ldots \ldots \ldots \ldots \ldots \ldots \ldots \ldots \ldots \ldots \ldots 5$

Appendix G Bibliography: Solar Advocates $\ldots \ldots \ldots \ldots \ldots \ldots \ldots \ldots \ldots \ldots \ldots, 57$ 


\section{LIST OF TABLES}

$\underline{\text { Page }}$

2-1 Value Cluster Definitions............................. 9

3-1 Policy Makers: Relative Emphasis Within and Among

Value Clusters ....................................... 12

3-2 Proportionate Frequency of Cluster Mentions of Policy

Makers: Disaggregated ................................ 14

3-3 Advocates: Relative Emphasis Within and Among

Value Clusters ....................................... 16

3-4 Proportionate Frequency of Cluster Mentions of Advocates:

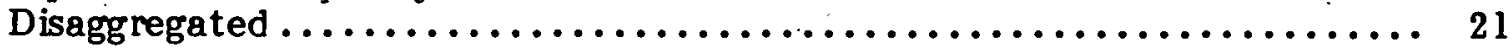

4-1 Relative Emphasis and Proportionate Frequencies of

Policy Makers' and Advocates' Value Clusters ...................... 24

\section{LIST OF FIGURES}

4-1 The Policy Maker's and the Advocate's Organization of

Value Clusters . 


\section{SERI}




\section{SECTION 1.0}

\section{INTRODUCTION}

Policy stands taken concerning solar energy are quite heterogeneous. Some people judge solar relative to other sources of energy on economic criteria alone. Others seem to argue for solar energy policies on other-than-economic criteria; e.g., social, environmental, and national security. Between these two extremes are many arguments for solar policies based on different mixtures of economic and other criteria. Thus, there are numerous policy stands having only a general technology in common.

The purpose of the present report is to study the various values associated with solar energy policies by discussants of such policies. The report is focused primarily on solar energy policy makers and advocates. This is because a literature review indicated that meaningful differences exist between these two salient groups and that studying such differences may clarify the roots from which they originate, namely values and their relative importance. However, policy makers and advocates as defined below are not the only groups concerned with solar energy policy. An obvious group whose values are important to solar energy policy is the public at large. The values of this group are not discussed because the secondary data upon which this study rests did not include detailed enough information about the public at large.

\subsection{OBJECTIVES}

The objectives of the present study are to:

- identify and define the various values that policy makers and solar advocates associate with solar energy,

- cluster and rank-order the above values when possible, and

- discuss differences between the two groups, and the resulting implications.

The findings from this study may be useful to solar energy policy researchers, policy makers, and planners. To policy researchers, the findings may be useful because they constitute a guide to social values that policy makers associate with solar energy. An example of research using social values as variables in its econometric model is the Strategic Planning Project of the Solar Energy Research Institute.* Among other variables, the project uses values associated with various solar technologies in order to rankorder such technologies according to their expected benefits to society. In the past, the project has assigned equal weights to all values, but as shown in this report the above practice may have to be changed. To solar energy policy makers as a group, the findings may help clarify the social values that their policies may help bring about or reinforce.

*Stevenson, R.; Koontz, R.; Bryant, B.; Burns, B. Prioritization of Solar RD\&D Budget Allocation Analysis. Golden, CO: SERI; March 1979. This source is referred to as the Strategic Planning Project in later sections of this report. 


\subsection{DEFINITION}

\subsubsection{Public Polieg Makers}

Solar energy policy makers include those people within the U.S. Department of Energy (DOE) and those scattered elsewhere throughout the govenment who are responsible for designing, implementing, and evaluating solar energy policy. However, for the purposes of this report, policy makers include only those whose opinions and/or decisions were documented. The diversity of sources for such opinions and decisions ranging from the President's Council on Environmental Quality to Congressional Hearings is shown in the bibliography under "policy makers."

Though solar energy policy makers are not a homogeneous group, they nevertheless seem to express similar values in discussing solar energy policy. Their starting assumptions and perceptions pertaining to the energy crisis have led them to recognize the need for energy policies designed to achieve two related goals:

- energy conservation which may reduce the growth in oil imports; and

- development of new sources of energy, particularly solar energy.

Policies to achieve these goals are not yet entirely in place. However, according to the Council on Environmental Quality, "The prospects for solar energy are brighter than most imagine" [1]. This council also estimates that up to one-fourth of the energy needs of the United States can be supplied" from solar sources by the year 2000.* While other estimates are less optimistic, they are nonetheless consistent with the expectation that solar energy may be a major source of energy in the foreseeable future.

Realizing that the adoption of solar energy may have far reaching economic and social implications, policy makers carefully examine the problems and promises associated. with solar energy. In doing so, they address themselves (usually only implicitly) to numerous social and economic values and discuss or imply the consistencies and inconsistencies between such values and policies aimed at increased use of solar energy.

In ways that are described in the methodology section, the present study attempts to identify and cluster the values that policy makers associate with the use of solar energy, as well as to rank-order such clusters.

\subsubsection{Advocates}

"Solar energy advocates" refer to those people who actively support a more rapid adoption of solar technologies. They of ten are drawn from environmental and other social movements, yet they may include two distinct subgroups: (1) those advocating solar energy in the political arena, and (2) those actually designing and adopting solar technologies at the local, grass roots level. Despite such differences among advocates, they constitute a group that is distinct from policy makers. The diversity of advocates' opinions ranging from narrow-scope commentaries to wide-scope social plans is indicated in the bibliography under "advocates."

*President Carter established the goal of $20 \%$ of energy consumption to be supplied by solar energy by the year 2000 . 
Most germane to the definition of advocates, however, is the basic orientation treating solar energy issues on broad social and ethical grounds. In this respect, one may characterize solar advocates as representing a grass roots social movement designed to build a "solar culture" rather than merely a "solar industry." Advocates, such as Hazel Henderson, Barry Commoner, and Herman Daly, tend to conceptualize the energy crisis and the need for an aggressive solar energy policy as a part of the need for broader social reform. Such reform is based on environmental conditions and constraints and on humanistic-ethical criteria. Only on this ethical basis should a social, productive, and economic system be designed. Their belief is that many current problems are the result of reversing the above order, thus creating a situation in which society's productive and economic systems are alienated from higher-order environmental and ethical needs [2].

Though solar energy advocacy is only a part of desired social reforms, it is nevertheless possible to ident ify and group solar-energy-related values of advocates, as explained and executed later in this report.

\subsubsection{Values}

A value is an enduring belief that determines general standards of conduct. As such, values influence behavior in many different ways, yet they are almost independent of specific situations. The value of safety, for example, may have an impact on the way one drives one's car, protects one's home, or perceives the use of solar versus other sources of energy. As a result, the number of values that one holds is rather limited (a dozen and a half or more, depending on the extent to which values are made specific), and their impact on behavior is indirect through their impact, for example, on beliefs and attitudes. In addition, value change tends to be a very slow process $[3, \mathrm{p} .7]$.

\subsubsection{Terminal versus Instrumental Values}

Terminal values pertain to end states of existence, while instrumental values relate to the means by which terminal values may be achieved. Since most end states of existence may be achieved by more than one means, the number of instrumental values is necessarily larger (a few times larger, according to Rokeach) than the number of terminal values. An exemplary list of terminal values measured by Rokeach includes the following 18 values (not ranked) $[3$, p. 359$]$ :

Freedom (independence, free choice)

National Security (protection from attack)

A World of Peace (free of war and conflicts)

Equality (brotherhood, equal opportunity for all)

Inner Harmony (freedom from inner conflict)

Salvation (saved, eternal life)

A Comfortable Life (a prosperous life)

An Exciting Llfe (a stimulating, active life)

A World of Beauty (beauty of nature and the arts)

Family Security (taking care of loved ones)

Happiness (contentedness)

Mature Love (sexual and spiritual intimacy)

Pleasure (an enjoyable, leisurely life)

Self-Respect (self - esteem) 
Social R ecognition (respect, admiration)

True Friendship (close companionship)

$W$ isdom (a mature understanding of life)

A Sense of Accomplishment (lasting contribution)

It is perhaps easier now to see that each of the above end states of existence may be acheived through many different instrumental values. It also may be useful to note that only some of the above terminal values seem directly related to solar energy. Yet, the distinction between terminal and instrumental values too of ten is confused by using a given value in both ways. For example, the value of decentralization as it pertains to solar energy may be either terminal (e.g., "small is beautiful") or instrumental toward a number of social, economic, or environmental ends. Further, some terminal or instrumental values can be used in either a personal or public manner. For example, the terminal value "security" may relate to either private, community, or national life.

\subsubsection{Value System}

A value system pertains to the subjectively consistent manner in which one organizes one's values, beliefs, attitudes (central and peripheral), and behavior. Each value may generate a number of beliefs, each belief may in turn generate a number of attitudes, and so forth. Though one's value system is organized in a subjective manner, societies tend to hold similar sets of values, differing only in the way they rank-order values. For example, members of the American society tend to hold similar terminal values, yet they may differ in the way they organize such values on racial background, sex, and age [3; 4].

Values, beliefs, and attitudes usually are not enumerated explicitly in policy settings because the concept of value system is a theoretical construct. Instead, statements of policy goals of ten are tangible results from which values may be inferred.

A value system in general, and values and beliefs in particular, also is characterized by being rather stable over time. Yet, drastic internal or external forces may require or trigger a rapid change in values. For example, it may be suggested that the oil crisis and its social impact in the past few years presented undesirable value trade-offs with everincreasing frequency. Prior to the oil embargo, economic prosperity, including a better lot for the disadvantaged, and enhanced environmental quality seemed mutually obtainable. The energy crisis challenged this optimism by causing frequent price escalations and, hence, a shift of political and economic powers from consumers to producers.

An energy policy based on renewable sources, such as solar energy, may offer in principle a solution to the energy crisis. It may do so not only by offering a technical solution, but also by creating a viable hierarchy of values. However, solar energy policy makers tend to evaluate solar energy incrementally according to its potential to solve the energy crisis, while solar energy advocates tend to evaluate solar energy according to its consistency with desired social reforms.

Thus while the values associated with solar energy by policy makers and solar advocates at least have a broad technology in common, there are no assurances that a conflict between the two groups will not be embodied in differences in value hierarchies. 


\subsubsection{Values and Public Policy}

Social values rarely enter public policy decisions explicitly. Rather, they are implicitly expressed in such decisions [5]. To find out what social values guide policy objectives, it is necessary to question policy makers directly or make inferences from their policy decisions. Thus, paradoxically, the most basic guide of public policies, i.e., social values, is not expressed in policy objectives and must be found out indirectly.

In ways described later in this report, the social values that policy makers and advocates associate with solar energy are identified, rank-ordered, and discussed. 
SEPI䊁 


\section{SECTION 2.0}

\section{METHODOLOGY AND PROCEDURE}

In order to identify, define, cluster, and rank-order values, the following methodology was utilized:

- review the literature pertaining to solar energy policy making and to solar advocacy in order to identify the universe of values discussed by them,

- use content analysis to classify and cluster the values that each group associates with solar energy, and

- based on the above, rank-order the value clusters of each of the two groups and compare them.

To carry out the above methodology, the following procedure was used.

(1) The universe of literature concerning social values and solar energy of policy makers and advocates was identified. This was done by consulting the Social Science Citation Index for general literature in the field and other bibliographical resources of SERI's Solar Energy Information Center for sources that relate more directly to solar energy policy.

(2). Once the population frames for policy makers and advocates were established, a judgmental sample of literature was selected for each group. Criteria for selecting such samples were: (1) the prominence of the source, (2) its perceived impact on policy, and (3) the need for a mix and a diversity of sources within each group.

(3) For each source, individual mentions or inferences of values were identified by the authors. The list of values identified from each source is provided in Appendix A.

(4) Values identified in step 3 were clustered using criteria to maintain completeness and accuracy yet enhancing the manageability of the raw data. More specifically:

(a) A small number of clusters that are representative of the raw (and large number of) values was identified in a manner discussed below. Clusters included economic, environmental, security, social, and ethical values.

(b) Cluster categories were designed to maximize the comparability of policy makers' and advocates' values with each other. Thus, internal consistency was assumed within each source and group in their classifications of values. For example, if each of two policy makers cited employment opportunities as a value of solar energy, then this value would be assigned both times to the same, broad value category: economic.

(c) Accuracy was maintained by clustering the values as the particular policy maker or advocate would have clustered them. To continue the previous example, if a policy maker specifically identified the employment benefits of solar energy in a social rather than an economic context, then the value in this instance was placed in the social value cluster. Following this procedure, each value mention was given a score of " $l$ " that was assigned to a 
single value cluster or divided among a few clusters. Often, specific values were listed by the source in a manner that made them fit into one of the five clusters almost automatically.

(d) To assure reliability, data were coded by each of the authors independently. In most cases this produced similar value definitions and clustering. In those cases in which inconsistencies occurred, compromise was reached.

(e) Definition of value clusters was designed to correspond to accepted definitions of such values. For example, economic value was defined as pertaining mainly to fulfillment of standard economic goals.

Table 2-1 defines the five clusters that emerged, and Appendices $\mathrm{B}$ and $\mathrm{C}$ provide a taxonomy of such values that are specific to policy makers and advocates, respectively.

(5) Once the objectives of value identification, definition, and clustering were completed, two methods were used simultaneously to rank-order, or otherwise establish, a lierarchy umorig these values for each of the two groups:

(a) Frequency Distribution-the frequency with which each value category was mentioned by a given source provided some indication of the value's perceived importance. Thus, the frequency with which each source mentioned or implied a particular value as being attributable to solar energy was determined first as a raw number and second as a proportion of all value mentions by that source. For each source, the relative frequency with which each value cluster was mentioned can be seen in Appendix A.

For the solar advocates, the means of the proportions identified by each author were computed. Implicit here is the assumption that each author, not each value mention or each article, is given equal weight, subject to the literature-selection criteria discussed above. This was done because manuscripts of different lengths (e.g., a book versus an article) would have introduced biases.

Frequency distribution analysis was slightly more complicated in the case of the policy makers. Several of the sources (i.e., Congressional hearings) contained the comments of more than one individual or agency. This was particularly common among individual members of Congress. Because these individuals generally exert their policy-making influence through the collective influence of each house of Congress, they are aggregated into "House" or "Senate" source categories prior to determining the mean proportion of each value's mention or inference. The sensitivity of results for policy makers to this procedural judgment is indicated in Appendix D.

(b) The value system or hierarchy held by each of these groups may not be indicated completely by the frequency with which the values are mentioned. A careful reading of a given source may indicate a logical hierarchy of values, which does not necessarily correspond to the results indicated by a frequency analysis. For example, if a particular value is mentioned of ten as being instrumental to the attainment of a higher-order terminal value, then the frequency of mention of the instrumental value really is reflective of the importance of the related terminal value. To measure this via frequency analysis alone would be to lose much of the meaning and depth of 
Table 2-1. VALUE CLUSTER DEFINITIONS

\begin{tabular}{|c|c|}
\hline Value Cluster & Definition $^{\mathrm{a}}$ \\
\hline Economic & $\begin{array}{l}\text { Includes values that pertain to the attainment of traditional economic } \\
\text { goals, such as efficiency (i.e., cost effectiveness), stability, growth, } \\
\text { and equity, as well as a broader definition of efficiency addressing } \\
\text { the need to include quantifiable social costs and benefits in economic } \\
\text { decision making. Also included are economic measures to achieve } \\
\text { not-entirely-economic values; e.g., employment which may be } \\
\text { thought of as a social as well as an economic value. }\end{array}$ \\
\hline
\end{tabular}

Environmental Includes values that refer to the ecosystem either in its inherent qualities (e.g., natural beauty and landscape) or in the goods or services it can provide (e.g., renewable resources). It is concerned with the need to offer a permanently safe, healthy environment in which people can live harmoniously with nature.

Social Includes the myriad of sociopolitical goals that a society might define. It pertains primarily to groups rather than individuals. Examples include democracy, justice, political freedom, community, and national unity and purpose.

Ethical Includes values pertaining to basic human rights and ideals not necessarily within a sociopolitical context. It is focused on the individual and includes such values as personal choice and fulfillment, and religious, spiritual, and cultural life.

Security

Includes values that lead to a reduction in perceived vulnerability or real risk for persons, communities, or the nation.

aplease note that it is not clear that the above clusters are mutually exclusive. In the social sciences, oblique relationships among factors rather than mutually exclusive relationships of ten depict reality more accurately.

the analysis that many of our sources include. Thus, content analysis of a purely analytical nature was done in parallel to frequency analysis. Quotes, paraphrases, and diagrams of the logical hierarchies established in several of the sources are included as Appendix $E$ in order to establish the internal validity of judgments made in this manner.

One final note relates to the fact that social values are extracted from secondary data; i.e., from public statements. It may be argued that such statements may not accurately reflect the value structure of policy makers and advocates. On the other hand, primary data collected from both groups pertaining to social values, which they associate with solar energy, may be subject to a more severe bias in that both groups will report values which will enhance their image in the public rather than report their actual values. In this respect, content analysis of secondary data may produce a more accurate depiction of the social values of the two groups. 


\section{S=Pl}


$i$

\section{SECTION 3.0}

\section{FINDINGS}

\subsection{POLICY MAKERS: VALUE CLUSTERS}

Of the five generic clusters depicted in Table 2-1, policy makers tend to identify only four that they believe may be enhanced by the adoption of solar energy: economic, security, social, and environmental values. Policy makers rarely discuss or justify the need for solar energy policy on the basis of the fifth value cluster pertaining to ethical values.

Table 3-1 summarizes the relative emphasis within and among value clusters of policy makers and the frequency with which these clusters are mentioned.

\subsubsection{Economic Values}

When policy makers address the economics of solar energy, they do so mainly in terms of its potential for efficiency or cost effectiveness. They perceive the need to produce solar energy at the lowest relative price. Yet, recent efforts to incorporate social costs and benefits (e.g., pollution and risk, and their opposites-a clean environment and reliability) into cost accounting have broadened the economic view of some policy makers. Thus, policy makers' notions of cost effectiveness are limited to the "quantifiable," a limit not generally imposed by advocates.

Policy makers also associate solar energy with the economic value of growth (even limitless growth). They value enhanced economic equity and also cite solar energy's job and small business creativity potential. However, they appear to reject the notion that solar energy policy should be designed to increase social or political equity. Finally, while policy makers also value economic stability, they generally do not associate this value with solar energy policy. As can be seen in Table 3-1, 51\% of all values fall within this definition of the cluster of economic values.

\subsubsection{Environmental Values}

Unlike oil and coal, solar energy is perceived by policy makers as an environmentally desirable energy source. Solar energy is clean and safe; it does not have negative effects on health and is nondepletable. But, policy makers of ten perceive only positive environmental impacts of solar energy and, unlike solar advocates, fail to realize that it might be used in a manner that also could have negative environmental impacts.

Values grouped in the environmental values cluster account for $17 \%$ of all value mentions.

\subsubsection{Security Values}

Policy makers almost exclusively define solar energy's security-enhancing value on the national level. It is seen as a means to reduce the nation's vulnerability to the possibility of energy embargo (and price increases) and, thus, strengthen their sense of national independence. This need is perhaps best symbolized by the recent statement of President 


\section{Table 3-1. POLICY MAKERS: RELATIVE EMPHASIS WTHHN AND AMONG VALUE CLUSTERS}

\begin{tabular}{|c|c|c|}
\hline Value Cluster & $\begin{array}{l}\text { Emphasis within } \\
\text { Cluster }\end{array}$ & $\begin{array}{l}\text { te Frequency of } \\
\text { Mentions } \\
\text { Men }^{\mathbf{a}}\end{array}$ \\
\hline Economic & $\begin{array}{l}\text { Efficiency } \\
\text { Growth } \\
\text { Short-Run } \\
\text { Employment } \\
\text { Competition } \\
\text { Intranational equity }\end{array}$ & $51 \%$ \\
\hline Environmental & $\begin{array}{l}\text { Compliance with environmental } \\
\text { standards (safety \& health) } \\
\text { Short-run orientation }\end{array}$ & $17 \%$ \\
\hline Security & U.S. national security & $15 \%$ \\
\hline Social & $\begin{array}{l}\text { Minimum impact } \\
\text { Indifference to scale }\end{array}$ & $15 \%$ \\
\hline Ethical & Benefit to mankind & $1 \%$ \\
\hline
\end{tabular}


Carter, "We intend ... to control our use of energy, and thereby to control our own destiny as a nation."

The potentially decentralized nature of some solar technologies may further enhance national and community security by diminishing the risk of terrorism. Enhanced community and personal security may benefit indirectly from increased national energy independence brought about by solar adoption. These, however, rarely are mentioned by policy makers. Values grouped in the security value cluster account for $15 \%$ of all value mentions.

\subsubsection{Social Values}

Policy makers rarely argue for solar energy on social or sociopolitical grounds. Employment opportunities, a preference for minimal social impacts, and indifference to scale are social values common to most policy makers. But, the social value of solar energy may extend in two opposite directions: some policy makers (e.g., the liberal members of Congress) view solar as a vehicle to bring about social reform of the nature generally associated with advocates, while other policy makers mention the value of solar energy as a means to avoid what they fear to be impending social disintegration and hope that solar energy can be adopted with a minimum social impact. Thus, these few value mentions make it difficult to quantify the social values of solar energy from secondary sources alone. Nevertheless, values grouped in the social value cluster account for $15 \%$ of all value mentions.

\subsubsection{Ethical Values}

Policy makers rarely mention solar energy policy in an ethical context. When such mentions do occur, they are generally in a broad context, such as benefits all mankind.

\subsection{POLICY MAKERS: RANK-ORDERING OF VALUE CLUSTERS}

Policy makers place heaviest emphasis on the economics of solar energy. Giving equal weight to each policy-making source, economic values receive $52 \%$ of all value mentions. On the other hand, environmental, security, and social values are mentioned in almost equal frequency: $17 \%, 15 \%$, and $15 \%$, respectively. Ethical values are mentioned only 1\% of the time. See Table 3-1 and Appendix D for details and scoring procedure.

Although one can feel confident of the internal validity and the reliability of these results, the external validity of the results is a function of the representativeness of our source of all relevant policy-making groups. This is because each group may evaluate the value clusters differently. An example of this is depicted in Table 3-2. Members of Congress $(n=15)$ appear to place greater emphasis on social and security values than do other policy-making sources as a whole. On the other hand, Congresspersons generally place less emphasis on economic and environmental values than do policy-making sources. Differences between the two houses of Congress also may be discerned in Table 3-2.

The quantitative results presented in Tables 3-1 and 3-2 not only complement our qualitative judgments of the data, but also complement them! Accordingly, economics is clearly the most important value criterion for policy makers. Solar energy, they believe, 
in

RR-329R

Table 3-2. PROPORTIONATE FREQUENCY OF CLUSTER MBNTIONS OF POLICY MAKERS: DISAGGREGATED ${ }^{\mathrm{Q}}$

\begin{tabular}{|c|c|c|c|c|c|}
\hline & \multicolumn{5}{|c|}{ Values Cluster } \\
\hline & Economic & Environmental & Social & Security & Ethical \\
\hline $\begin{array}{l}\text { Senate }{ }^{b} \\
\text { (94th Congress) }\end{array}$ & $30 \%$ & $8 \%$ & $25 \%$ & $35 \%$ & $1 \%$ \\
\hline $\begin{array}{l}\text { House }{ }^{c} \\
\text { (94th Congress) }\end{array}$ & 24 & 11 & 38 & 20 & 8 \\
\hline All Other Sources ${ }^{d}$ & 55 & 18 & 10 & 14 & 1 \\
\hline Total ${ }^{e}$ & 51 & 17 & 15 & 15 & 1 \\
\hline
\end{tabular}

${ }^{\text {apercentages rounded. }}$

${ }^{b}$ Based on individual values of Senators $(n=6)$ as mentioned or implied in Solar Energy Legislation through the 94th Congress [6]. Each Senator's values are given equal weight. See Appendix D for details.

"Based on individual values of Representatives $(n=9)$ as mentioned or implied in the source footnoted in "b" above.

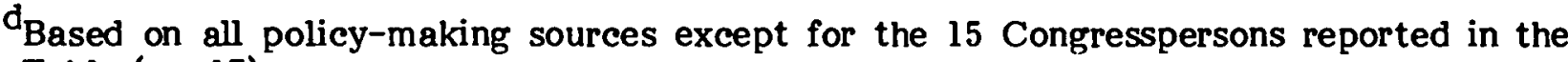
Table $(n=17)$.

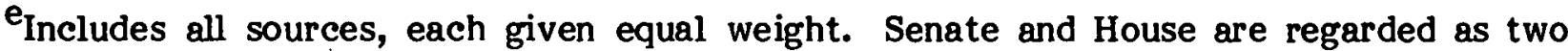
single sources; i.e., individual members of Congress are not disaggregated into discrete sources. This type of disaggregation would be necessary in a similar study focusing on the Congress. In the present study the values of Congresspersons are given the weight of two sources (Senate and House) so as to give some indication of the different policymaking values of the legislative branch. 
should be adopted in a manner consistent with the nation's economic well-being. It may take on an even greater role than may be indicated by frequencies reported in Tables 3-1 and 3-2. This is because policy makers sometimes view economic health as a central value associated with the need to enhance national security via achieving energy independence. Economics also may be valuable as an instrument toward environmental and health and safety improvements, if efficient price mechanisms develop. Environmental, social, and security values get similar scores, both quantitatively and qualitatively. Both ways, it is difficult to rank these three values, but they are clearly less important than economic values.

The totals shown in Table 3-2 summarize the values associated with solar energy as mentioned by policy makers. The totals avoid giving inordinate weight to individual Congresspersons whose comments were generally quite brief, but still take into account their collective voice via their policy-making bodies: the Senate and the House. Qualitative judgment confirms that members of Congress are a heterogeneous group with respect to the values they associate with solar energy. But the small sample size does not allow for a more substantive discussion of this matter. To test the above conclusions more fully, additional data from solar energy policy makers are necessary.

\subsection{ADVOCATES: VALUE CLUSTERS}

Advocates of solar energy address all generic value categories identified in Table 2-1. But from Table 3-3 and the discussion below, it can be seen that advocates tend to emphasize different aspects of the generic value clusters, as compared to policy makers.

\subsubsection{Social Values}

\subsubsection{Meaningful Choice through Decentralization}

- Solar energy is not only a potentially decentralized technology, but may imply a decentralized social organization as well. Solar advocates do not argue that a predetermined set of values of a solar future is superior to values characteristic of present society. Instead, decentralization breeds the potential for individual and community cholce and control of suciul desigins.

- Smallness can be held as a value in and of itself, as well as being conducive to inform ed participatory democracy, freedom, and independence.

\subsubsection{Directing Sociopolitical Treinds and Priorities}

While most advocates point out the breadth of social options that decentralized solar technologies provide, many express preferences for specific choices.

- Radicalism

Many advocates of a "solar culture" argue for radical change of values, technology, and the economy. A comprehensive review of social priorities has been cited as necessary to the adoption of solar energy in a manner consistent with the values of environmental harmony, justice, simplicity, security, and conservation. 


\section{Table 3-3. ADVOCATES: RELATIE EMPHASTS WTHIN AND AMONG VALUB CLUSTERS}

\begin{tabular}{lcc} 
Value Cluster & $\begin{array}{c}\text { Emphasis within } \\
\text { Clusters }\end{array}$ & $\begin{array}{c}\text { Proportionate Frequency of } \\
\text { Cluster Mentions }^{\mathrm{a}}\end{array}$ \\
\hline
\end{tabular}

Social

Personal independence

$32 \%$

Renewability

Economic

Appropriateness

$33 \%$

Material sufficiency

Long-run

Labor intensity

Competition

International equity

Intranational equity

Intergenerational equity

Environmental

Harmony with nature

Long-run impact on health and safety

Quality of life

Ethical

Personal fulfillment

$7 \%$

Decentralized choice

Sesurity

National and personal

$4 \%$ security

$a_{\text {This }}$ is the mean proportion, $\mathrm{p}$, of the frequency with which each reviewed source mentions or implies this value cluster. Thus, each source-not each value mention-is given equal weight. See Appendix $D$ for details. 
- Conservatism

The advocacy of solar energy can also be phrased legitimately in fundamentally conservative terms. Former Oregon Governor Tom McCall, or perhaps Governor Jerry Brown, typifies this approach. Values attributable to solar energy and consistent with conservatism include: (1) preservation of natural resources, small businesses, small farms, and the family unit; (2) free economic competition; (3) self-reliance; (4) national security; and (5) local control.

- "Two Paths"

Amory Lovins puts the issue of societal direction in somewhat different terms. He believes that society stands at crossroads and must choose between the "hard" nonrenewable nuclear path and the "soft" renewable diverse path identified with decentralized solar technologies [7].

These paths are mutually exclusive due to environmental (i.e., running out of time and resources) and economic (i.e., capital shortage) constraints. But the impact of the choice will be immense, thus encompassing the sociopolitical realm as well.

Beyond the hard-soft path choice, Lovins and his followers leave the establishment of social priorities to individuals and communities. They fear that current hard-path trends will lead to a destruction of political freedom and democracy, to be replaced by a police-state technocracy. On the other hand, choosing the soft-path would allow major social transitions and hopefully restore traditional American values, whether identified above as radical or conservative.

Values grouped in the social value cluster account for $32 \%$ of all value mentions.

\subsubsection{Economic Values}

\subsubsection{Economic Holism}

Some argue that solar advocates place little value on the economic costs and benefits of these technologies. While advocates may value environmental, ethical, and social ends achievable via solar adoption even more highly, much of this valuation fits within the broad confines of economics. The economic concept of internalizing external costs (i.e., making price reflect economic, environmental, and social costs) can help define the environmental and social values of solar energy. Decentralization may reduce the incidence of monopoly profits, another market imperfection. Still, to solar advocates the economic paradigm is fundamentally different, more holistic than conventionally defined. Traditional economic goals include efficiency, equity, stability, and growth. Solar advocates generally transform the last two goals into sustainability and sufficiency.

\subsubsection{Efficiency}

To advocates, efficiency is an instrumental value. Commoner and Georgescu-Roegen argue for solar energy on, the grounds that economic efficiency must conform to the physical constraint of thermodynamic efficiency [8;9]. Others argue that solar 
technologies can utilize scarce capital more efficiently, particularly when net energy production is considered. Decentralization is also efficient as competition is enhanced and energy-producing capacity can be adjusted in finer increments. Hence, advocates value the notion of appropriate scale.

\subsubsection{Equity}

Advocates believe that adopting solar energy will lead inherently to a more equal distribution of wealth (hence, power) within the United States and internationally. Factors cited include the labor intensity of solar technologies, creating both skilled and unskilled jobs; decentralization of economic power; and the creation of small businesses. Commoner speaks of an economic democracy created by the solar transition.

\subsubsection{Stability versus Sustainability}

While macroeconomic stability concerned with reducing the swings of the business cycle is a traditional economic value, sustainability takes a longer-term view. Advocates believe that renewability will lead to the preservation of the energy base for the economy. Most importantly, this resource base should not increase in price since its scarcity will not decrease with time.

\subsubsection{Growth versus Sufficiency}

Economic growth is less clearly valued by advocates as compared to policy makers. Most advocates would probably agree with Hazel Henderson that society has confused progress with momentum [10, p. 16]. Advocates generally believe that many Americans have already achieved (or surpassed) a sufficient level of material wealth, and that further such growth is not desirable. Personal and cultural growth may be attainable by the adoption of solar energy but conventional economic measures would not "capture" this improvement. Material growth for those who most need it may be enhanced via the potential job, business, and foreign market creation of solar energy. Bruce Hannon argues for maximum sustainable consumption, combining the values of growth, efficiency, and renewability $[11$, p. 80].

Values grouped within the economic value cluster account for $33 \%$ of all value mentions.

\subsubsection{Environmental Values}

\subsubsection{Holism}

To solar advocates, the environmental value of solar energy is not wholly captured by its subcomponents; e.g., pollution reduction, safety enhancement. Rather, it is the holistic, synergistic entity to which policy must conform that is treated as the value of the environment.

Holism posits that everything is related to everything else, regardless of time, space, species, or even tangibility; it is the interrelationships, not the individual parts, that are 
of central value. Based on this, advocates argue that people must live in a permanent, renewable, sustainable harmony with nature. Stewardship and conservation must characterize human interaction with the environment.

In practical terms, many advocates value a low throughput of resources; i.e., "the entropic physical flow of matter-energy from nature's sources, through the human economy, and back to nature's sinks" [12, p. 36]. In addition, advocates of ten put a negative value on industries and their by-products when inconsistent with holistic considerations; e.g., big oil, nuclear power.

\subsubsection{Health and Safety}

Like policy makers, advocates value solar energy's potential to enhance environmental health and safety. Predecessors of the solar advocates were and remain instrumental in efforts to see that environmental costs and benefits are built into, or "internalized" within, market price mechanisms; e.g., making polluters pay for the cleanup cost or for damages incurred. Though solar energy is held to be more environmentally benign than $i$ ts alternatives, solar advocates have led the way in recognizing that even solar technologies may pose environmental hazards $[13$, pp. 5,6$]$.

\subsubsection{Limits}

Because holism indicates the finite nature of physical resources, a further aspect of the enviromental ethic espoused by solar advocates is one of self-imposed limits. Frugality, humility, self-discipline, and restraint become virtues in a world where environmental limits necessitate careful conservation. Interdependence and a need for social planning are potential consequences.

These considerations of holism, health and safety, limits, and related values, when combined, yield what may be regarded as the advocates' "environmental ethic." As a value cluster, it accounts for $24 \%$.

\subsubsection{Ethical Values}

In addition to environmental values, advocates also hold humanistic values as central to the ethical criteria upon which solar energy policy should be based. The relative simplicity and accessibility of many solar technologies open the door to a broad range of desirable terminal values. Adoption of decentralized solar technologies may directly contribute to self-reliance, rewarding employment opportunities, and creativity. Personal freedom and growth, leading to enhanced aesthetics and cultural evolution, are envisioned as the logical and desirable end result. The attainment of these humanistic values is premised on the personal security that these technologies may provide.

Ethical values account for $7 \%$ of all value mentions. As shown in the qualitative analysis later in this paper, ethical values capture a quantitative score that is smaller than they actually deserve. 


\subsubsection{Community and National Security}

- Decentralization may lead to reduced community and national vulnerability to interruption of energy supplies.

- Renewability should be at least as effective as decentralization in diminishing related vulnerability in the medium and long term.

- Solar energy may enhance the prospects for peace and disarmament by reducing the potential for nuclear proliferation.

- International conflicts over scarce energy resources may diminish as solar energy is adopted.

Values grouped in this cluster account for $4 \%$ of all value mentions.

\subsection{ADVOCATES: RANK-ORDERING OF VALUE CLUSTERS}

As shown in Table 3-3, advocates place equal emphasis on economic and social values (33\% and $32 \%$, respectively). Environmental values also receive prominent attention from advocates (24\%). Ethical values, which were nearly ignored by policy makers, receive $7 \%$ of all value mentions. Security values account for only $4 \%$ of value mentions. Details and the scoring procedure are provided in Appendix D.

In a manner similar to the treatment of policy makers in Section 3-2, the issue of heterogeneity among advocates was examined. As can be seen in Table 3-4, advocates whose role is primarily political or usually addressed to a national constituency (e.g., Amory Lovins, Solar Lobby) are distinguished from those who take an active role in the grass roots adoption of solar energy in local communities. Key differences which can be noted are that grass roots advocates more frequently mention social values, primarily decentralization, than do national advocates, but their practical, local orientation results in the less frequent mention of ethical and security values. Both groups place high and nearly equal emphasis on economic and environmental values.

It should be stressed, however, that as the sample size of each of the two groups is rather small (altogether seven national advocates and four grass roots advocates), the results reported in Table 3-4 should be treated as a source for hypothesis generation rather than as conclusive research findings.

Proportionate frequency distribution of value mentions, however, does not give as accurate a picture of the values held by solar advocates as it does for the policy makers' values. Advocates tend to follow a well-defined hierarchical model of values that they have developed in response to their perception of society's energy dilemma. As a result, counting the raw number of advocates' values does not give an accurate representation of the hierarchical structure of their values.

Despite differences among advocates, they seem to agree that ethical and environmental values are of the highest order, with many ethical criteria necessarily being constrained to conform to environmental conditions. The function of social and economic systems is mainly to enhance the fulfillment of environmental and ethical values. Thus, social and economic systems are valued primarily as instruments to achieve environmental and ethical values. Yet, social values may be terminal as well, for advocates emphasize not 
only individual independence (an ethical value), but also interdependence and the cultural evolution this can bring about. Similarly, personal security is an ethical value as perceived by advocates, but national security is a value that is instrumental toward achieving other societal, environmental, economic, and ethical ends.

Table 3-4. PROPORTIONATE FREQUENCY OF CLUSTER MENTIONS OF ADVOCATES: DISAGGREGATED

\begin{tabular}{lcc}
\hline Value Cluster & National Advocates $^{\mathrm{a}}$ & Grass Roots Advocates $^{\mathrm{b}}$ \\
\hline Economic & $32 \%$ & $36 \%$ \\
Environmental & 25 & 23 \\
Social & 25 & 41 \\
Ethical & 10 & 0 \\
Security & 9 & 0 \\
\hline
\end{tabular}

ancludes Daly, Commoner, Hayes, Shurcliff, Solar Lobby, Henderson, and Lovins.

bincludes all other advocate sources. See Appendix G, Bibliography: Solar Advocates. 


\section{SERI数}




\section{SECTION 4.0}

\section{COMPARISON OF THE VALUES OF \\ POLICY MAKERS AND ADVOCATES}

The preceding sections discussed the social values of policy makers and advocates regarding solar energy. Taking into account the relative emphases these two groups place on various components within social value categories, it is possible to compare the proportionate frequency distribution of the groups' value clusters. A discussion follows of a basic difference in the way advocates and policy makers organize their value clusters, as well as some implications for a quantitative analysis.

\subsection{REL.ATIVE EMPHASIS}

Table 4-1 presents a summary of the relative emphasis that policy makers and advocates place on various categories of social values. As the table shows, even when policy makers and advocates address the same cluster of values, these groups often differ as to the relative emphasis they put on subcomponents of the cluster.

\subsubsection{Economic Values}

Both policy makers and advocates discuss the economic values of solar energy policies. Policy makers, on the one hand, tend to view the values from the perspective of the "economic model of man," stressing cost effectiveness, efficiency, and growth. On the other hand, advocates tend to view economic values from a social perspective, emphasizing appropriateness and material sufficiency.

\subsubsection{Security Values}

Policy makers tend to value the increased national security that results from reduced dependence on foreign energy supplies and the long-term national security provided by renewable energy sources. Advocates value national security and personal security as well, believing that both would be enhanced by decentralized renewable energy systems.

\subsubsection{Social Values}

Policy makers believe that solar energy technologies should be utilized without regard to their social impact; policy makers are indifferent to the scale of these energy developments and to the institutions they create. Advocates believe that utilizing solar energy can be an integral part of major social reforms. Additionally, advocates favor a decrease in overall development scale and an increase in individual and community choice and in social equity.

\subsubsection{Environmental Values}

Policy makers value solar energy's potential to comply easily with environmental, health, and safety standards. Going further, advocates believe that solar energy is compatible with a sustainable harmony of nature and technology. 
Table 4-1. RELATIVE ERPHASIS AND PROPORTIONATE FREQUENCIES OF POLICY MAKERS' AND ADVOCATES' VALUE CLUSTERS

\begin{tabular}{|c|c|c|c|c|}
\hline Value & Policy Makers & Frequency $^{\mathrm{a}}$ & Advocates & Frequency $^{\mathrm{a}}$ \\
\hline Economic & $\begin{array}{l}\text { Efficiency } \\
\text { Growth } \\
\text { Short-run } \\
\text { Employment } \\
\text { Competition } \\
\text { Intranational } \\
\text { equity }\end{array}$ & $51 \%$ & $\begin{array}{l}\text { Appropriate } \\
\text { Material sufficiency } \\
\text { Long-run } \\
\text { Labor intensity } \\
\text { Competition } \\
\text { International equity } \\
\text { Intranational equity }\end{array}$ & $33 \%$ \\
\hline Security & $\begin{array}{l}\text { U.S. national } \\
\text { security } \\
\text { National inde- } \\
\text { pendence } \\
\text { Renewability }\end{array}$ & 15 & $\begin{array}{l}\text { National and personal } \\
\text { security } \\
\text { Decentralization } \\
\text { Personal independence } \\
\text { Renewability }\end{array}$ & . \\
\hline Social & $\begin{array}{l}\text { Minimum impact } \\
\text { Indifference to } \\
\text { scale }\end{array}$ & 15 & $\begin{array}{l}\text { Social change } \\
\text { Small scale } \\
\text { Social equity }\end{array}$ & 32 \\
\hline Environmental & $\begin{array}{l}\text { Compliance with } \\
\text { environmental } \\
\text { standards } \\
\text { (safety \& health) } \\
\text { Short-run impact } \\
\text { on health and } \\
\text { safety } \\
\text { Quality of lifo }\end{array}$ & 17 & $\begin{array}{l}\text { Harmony with } \\
\text { nature } \\
\text { Long-run impact } \\
\text { on health and. } \\
\text { safety }\end{array}$ & 24 \\
\hline Ethical & Benefit to mankind & 1 & $\begin{array}{l}\text { Personal fulfillment } \\
\text { Decentralized choice }\end{array}$ & \\
\hline
\end{tabular}

${ }^{2}$ This is the mean proportion, $p$, of the frequency with which each reviewed source means or implies this value cluster. Thus, each source-not each value mention-is given equal weight. See Appendix D for details. 


\subsection{RANK-ORDERING}

As shown in Table 4-1, policy makers rank economic values first (51\%); environmental, security, and social values second, third, and fourth (17\%, 15\%, and 15\%, respectively*); and ethical values last. On the other hand, advocates give economic and social values equal rank (33\% and $32 \%$, respectively), followed by environmental values (24\%), ethical values (7\%), and security values (4\%).

This ranking, however, does not present an entirely accurate account of the way policy makers and advocates organize their value clusters. The reasons for this are discussed in the next section.

\subsection{QUALTATIVE DIPPERENCES}

The shortcomings of the quantitative analysis above are particularly apparent in the case of advocates. The advocate sources which were reviewed clearly indicated that many attributes of solar energy are instrumental toward achieving the first-order priority of living in an environmentally sound manner. Even ethics must conform to holistic environmental constraints. On the other hand, policy makers tend to treat many values from an economic perspective. An illustration of the differences between the two groups is presented in Figure 4-1.

Advocates place ethical and environmental (especially) values at the focus of their attention (hence, illustratively, at the bottom of the funnel shown in Figure 4-1) because these values are terminal. Economic tools, social design, and national security are instrumental toward achieving desired ethical and environmental ends. Advocates apparently believe that economic and social values can be useful particularly with respect to making solar energy conform to desired ethical and environmental values. As a result, economic and social values receive frequent mention, which reflects the importance of ethical and environmental values.

For policy makers, on the other hand, economics appears to be not only the most important criterion for establishing the value of solar energy, but also it is a model within which policy makers wish to conceive all other values. They seem to use a model in which all values can be somehow quantified, resulting in a decision function that relies only on economic instruments to achieve a number of valued ends. Thus, economics finds its place at the bottom of the funnel shown in Figure 4-1 because all values seem to be translated into economic language.

*Because the percentage differences among these three values are minimal, they may be regarded as having equal ranks. 


\section{Advocates}

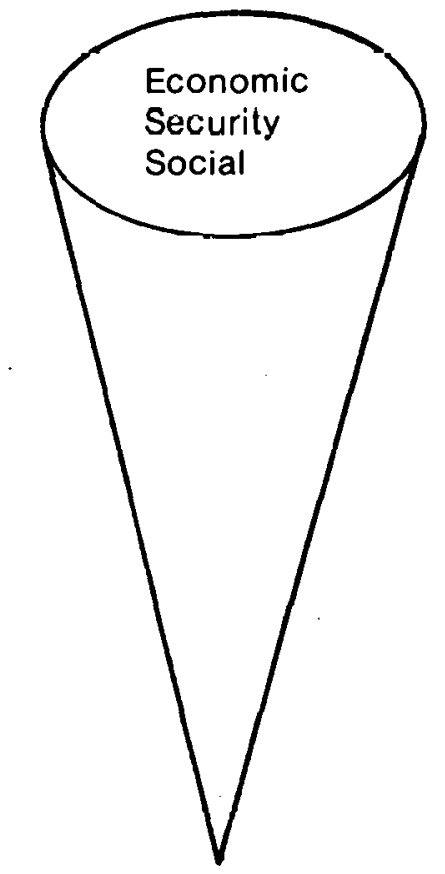

Ethical

Environmental

\section{Policy Makers}

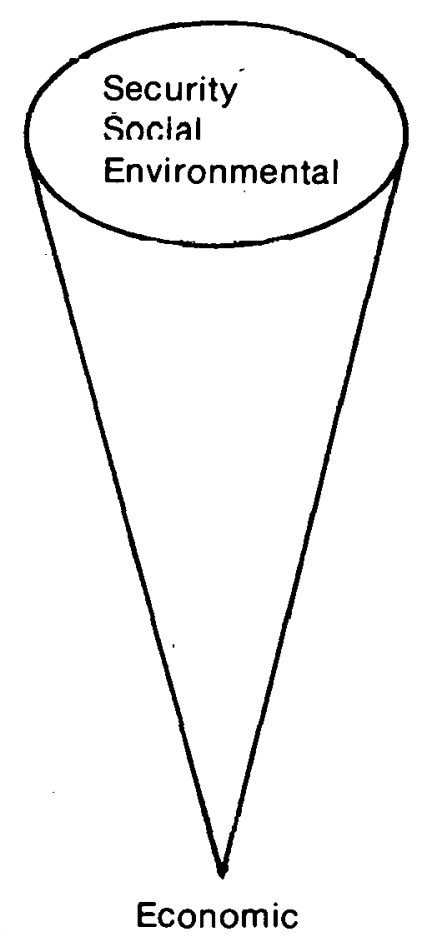

Figure 1. The Policy Maker's and the Advocate's Organization of Value Clusters 


\section{SECTION 5.0}

\section{CONCLUSION}

As we have seen, solar energy policy makers and advocates hold significantly different hierarchies of values. This extends both to the way they define their values and to the relative weight they assign to such values. We believe that this difference in value orientation is a very plausible reason for the differences in policy orientation exhibited by the two groups. But this difference and other questions raised by this study remain to be more fully explored in the future. The collection of primary data to verify the values of policy makers and advocates and to ascertain those of the public at large is the first priority for further research. Such data"should be used to examine and perhaps revise or extend the findings of the present exploratory study.

Further investigation of the relative homogeneity or heterogeneity within the policy maker and advocate groups also appears necessary. While we defined policy makers and advocates as mutually exclusive groups, recent developments indicate that this distinction is becoming less and less valid because membership and values of the groups are increasingly overlapping.

The present study may already be useful to policy researchers and policy makers. To policy researchers needing information about social values associated with solar energy, the present study offers detailed information. For example, the Strategic Planning Project may use the value clusters and the weights obtained from the present study in its econometric model designed to rank-order the various solar technologies according to their expected benefits to society. Presumably, the resulting rankings may guide policy makers to optimally allocate Research and Development resources among the various solar technologies. In the past, the algorithm of the Strategic Planning Project has assigned equal weights to all social values. In view of our findings in the present study, the above practice will be modified. In addition, separate runs of the algorithm should be executed using the weights that policy makers and advocates assign to the various social values as indicated in Tables 3-1 and 3-3. This way, differences between policy makers and advocates would be clearly pointed out rather than somehow mixed within a single algorithm.

To solar energy policy makers as a group, the findings of the present study may help clarify the social values that their policies may help bring about or reinforce. In addition, the findings also expose them to an alternative value hierarchy-that of the advocates. 


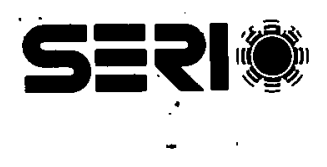




\section{SECTION 6.0}

\section{REPERENCES}

1. President's Council on Environmental Quality. Solar Energy: Progress and Promise, 1978. 1979.

2. Commoner, Barry. The Poverty of Power. New York: Alfred A. Knopf, Inc.; 1976.

3. Rokeach, Milton. The Nature of Human Values. New York: The Free Press; 1973.

4. Hornick, William; Enk, Gordon. Value Issues in Technology Assessment. Rensselaerville, NY: The Institute on Man and Science; 1978.

5. Kaplan, Abraham. American Ethics and Public Policy. New York: Oxford University Press; 1963.

6. Solar Energy Legislation through the 94th Congress. 1976.

7. Lovins, Amory. Soft Energy Paths: Toward a Durable Peace. Cambridge, MA: Ballinger Publishing; 1977.

8. Commoner, Barry. "Reflections: The Solar Transition, II." New Yorker. 30 April 1979.

9. Georgescu-Roegen, Nicholas. The Enthropy Law and the Economic Process. Cambridge, MA: Harvard University Press; 1977.

10. Henderson, Hazel. "The End of Flat-Earth Economics and the Transition to Renewable Resources Societies." Alternatives. Winter 1978.

11. Hannon, Bruce. "Economic Growth, Energy Growth, Energy Use, and Altruism." Dennis L. Meadows, ed. Alternatives to Growth, I. Cambridge, MA: Ballinger Publishing Co.; 1977.

12. Daly, Herman. Steady-State Economics. San Francisco: W. H. Freeman and Co.; 1979.

13. "Hazards of Solar Energy." People and Energy. Nov.-Dec. 1978.

14. Shama, Avraham. Marketing in a Slow Growth Economy: The Impact of Stagflation on Consumer Psychology. New York, N. Y.: Praeger Publishing; 1980. 


\section{SE尺ㅋ.}




\section{APPENDIX A}

VALUES MENTIONED OR IMPLIED BY THE NDIVIDUAL POLICY MAKERS AND ADVOCATES

\section{Policy Makers}

\begin{tabular}{|c|c|c|c|}
\hline Source $^{a}$ & $\begin{array}{l}\text { Value Mentioned or } \\
\text {.Implied } b\end{array}$ & Value Cluster ${ }^{c}$ & $\begin{array}{l}\text { Total Mentions } \\
\text { within Each Source }\end{array}$ \\
\hline$\frac{\text { Solar Energy: }}{\text { Progress and }}$ & $\begin{array}{l}\text { Competitive } \\
\text { Growth } \\
\text { Small vs. large programs } \\
\text { Competition } \\
\text { Complexity } \\
\text { Realism } \\
\text { Environmental quality } \\
\text { Renewability } \\
\text { Increased employment } \\
\text { Feasibility } \\
\text { Safety } \\
\text { Equity }\end{array}$ & $\begin{array}{c}\mathrm{A} \\
\mathrm{A} \\
0.5 \mathrm{~A}, 0.5 \mathrm{~S} \\
\mathrm{~A} \\
0.5 \mathrm{~A}, 0.5 \mathrm{~S} \\
\mathrm{~A} \\
\mathrm{~A} \\
0.5 \mathrm{~A}, 0.5 \mathrm{~B} \\
0.75 \mathrm{~A}, 0.25 \mathrm{~B} \\
\mathrm{~A} \\
\mathrm{C} \\
0.5 \mathrm{~A}, 0.5 \mathrm{~S}\end{array}$ & $\begin{array}{l}\mathbf{A}=8.75 \\
\mathbf{B}=0.75 \\
\mathbf{S}=1.5 \\
\mathbf{C}=1.0 \\
\mathbf{n}=12.0\end{array}$ \\
\hline $\begin{array}{l}\frac{\text { National Energy }}{\text { Act, Refer- }} \\
\frac{\text { ence Informa- }}{\text { tion }[16]}\end{array}$ & $\begin{array}{l}\text { Reduce oil imports: } \\
\text { Growth } \\
\text { Efficiency } \\
\text { Equitable } \\
\text { Renewable } \\
\text { Control } \\
\text { Efficiency }\end{array}$ & $\begin{array}{c}\mathrm{C} \\
\mathrm{A} \\
0.75 \mathrm{~A}, 0.25 \mathrm{~S} \\
0.5 \mathrm{~A}, 0.5 \mathrm{~B} \\
\mathrm{C} \\
\mathrm{A}\end{array}$ & $\begin{array}{l}\mathrm{A}=3.25 \\
\mathrm{~B}=0.5 \\
\mathrm{~S}=0.25 \\
\mathrm{C}=2.0 \\
\mathrm{n}=6.0\end{array}$ \\
\hline$\frac{\frac{\text { National }}{\text { Program Plan }}}{[15]}$ & Cost effec tive & $\mathbf{A}$ & $\begin{array}{l}\mathrm{A}=1.0 \\
\mathrm{n}=1.0\end{array}$ \\
\hline
\end{tabular}

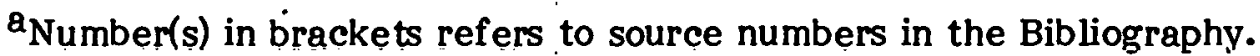

${ }^{b}$ Values appearing here were taken verbatim from the source; hence, they appear as nouns, adjectives, verbs, and phrases.

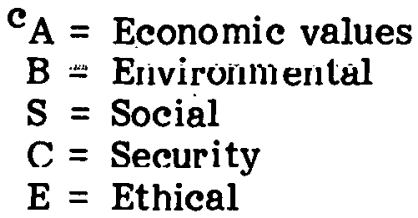

Each value mencion gets a score of " $1, "$ which may be subdivided among the various clusters.

$d_{n}=$ Total number of value mentions for each source. For proportionate frequency of mention for each cluster within each source, see Appendix D. 


\begin{tabular}{|c|c|c|c|c|}
\hline Source & Value Mentioned or Implied & Value Cluster & & Total \\
\hline$\frac{\text { Solar energy: }}{\text { Status Report }}$ & $\begin{array}{l}\text { Long-range planning } \\
\text { Healthy economy } \\
\text { Renewable } \\
\text { Inexhaustible } \\
\text { Economically competitive } \\
\text { Environmentally acceptable } \\
\text { Operationally safe } \\
\text { Cost } \\
\text { Reliability } \\
\text { Independence } \\
\text { Long-term } \\
\text { Renewable } \\
\text { Inexhaustible } \\
\text { Conservation } \\
\text { Fuel efficiency } \\
\text { Stability } \\
\text { Abundance } \\
\text { Technical progress } \\
\text { Health } \\
\text { Ecology } \\
\text { Social: national security } \\
\text { Employment } \\
\text { No change in life-style } \\
\text { Avoid catastrophic } \\
\text { occurrence } \\
\text { Individual control }\end{array}$ & $\begin{array}{c}\mathrm{S} \\
\mathrm{A} \\
0.75 \mathrm{~A}, 0.25 \mathrm{~B} \\
\mathrm{~A} \\
\mathrm{~A} \\
\mathrm{~B} \\
\mathrm{C} \\
\mathrm{A} \\
\mathrm{C} \\
0.75 \mathrm{~A}, 0.25 \mathrm{C} \\
0.5 \mathrm{~A}, 0.5 \mathrm{~S} \\
0.5 \mathrm{~A}, 0.5 \mathrm{~B} \\
\mathrm{~A} \\
0.75 \mathrm{~A}, 0.25 \mathrm{~B} \\
\mathrm{~A} \\
0.5 \mathrm{~S}, 0.5 \mathrm{C} \\
\mathrm{A} \\
0.75 \mathrm{~A}, 0.25 \mathrm{~S} \\
\mathrm{~B} \\
\mathrm{~B} \\
\mathrm{C} \\
\mathrm{S} \\
\mathrm{S} \\
\mathrm{C} \\
\mathrm{S}\end{array}$ & $\begin{array}{l}A \\
B \\
S \\
C \\
n\end{array}$ & $\begin{array}{l}=11.0 \\
=4.0 \\
=\quad 5.25 \\
=4.75 \\
=25.0\end{array}$ \\
\hline$\frac{\text { U.S. Energy }}{\frac{\text { Demand and }}{\text { Supply [18] }}}$ & $\begin{array}{l}\text { Growth } \\
\text { Reduced vulnerability } \\
\text { Growth } \\
\text { Conservation } \\
\text { Energy efficiency } \\
\text { Efficiency pricing }\end{array}$ & $\begin{array}{c}\mathrm{A} \\
\mathrm{C} \\
0.5 \mathrm{~A}, 0.5 \mathrm{C} \\
0.5 \mathrm{~A}, 0.5 \mathrm{C} \\
\mathrm{A} \\
\mathrm{A}\end{array}$ & $\begin{array}{l}\mathrm{A} \\
\mathrm{C} \\
\mathrm{n}\end{array}$ & $\begin{array}{l}=4 \\
=2 \\
=6\end{array}$ \\
\hline$\frac{\text { Solar Energy }}{\text { Policy }[7]}$ & Equity & $0.5 \mathrm{~A}, 0.5 \mathrm{~S}$ & $\begin{array}{l}A \\
S \\
n\end{array}$ & $\begin{array}{l}=0.5 \\
=\quad 0.5 \\
=1.0\end{array}$ \\
\hline$\frac{\text { Solar Powe: }}{\text { from }}$ & $\begin{array}{l}\text { Industry } \\
\text { Large scale } \\
\text { Cost eff ective } \\
\text { Resource conserving } \\
\text { Environmental compatibility } \\
\text { Social benefit } \\
\text { Industrialize space } \\
\text { National self-sufficiency } \\
\text { Trade balance } \\
\text { Employment } \\
\text { Limitlessness }\end{array}$ & $\begin{array}{c}\mathrm{A} \\
\mathrm{A} \\
\mathrm{A} \\
0.5 \mathrm{~A}, 0.5 \mathrm{~B} \\
\mathrm{~B} \\
\mathrm{~S} \\
\mathrm{~A} \\
\mathrm{C} \\
\mathrm{A} \\
0.75 \mathrm{~A}, 0.25 \mathrm{~S} \\
\mathrm{~A}\end{array}$ & $\begin{array}{l}\text { A } \\
\text { B } \\
\text { S } \\
\text { C } \\
n\end{array}$ & $\begin{array}{l}=8.25 \\
=2.5 \\
=1.75 \\
=1.5 \\
=14.0\end{array}$ \\
\hline
\end{tabular}




\begin{tabular}{|c|c|c|c|c|}
\hline Source & Value Mentioned or Implied & Value Cluster & & Total \\
\hline$\frac{\text { Solar Power }}{\frac{\text { from }}{\text { Satellites[1 }}}$ & $\begin{array}{l}\text { Social stability } \\
\text { Commercially attractive } \\
\text { Environmentally acceptable }\end{array}$ & $\begin{array}{c}0.5 \mathrm{C}, 0.5 \mathrm{~S} \\
\mathrm{~A} \\
\mathrm{~B}\end{array}$ & & \\
\hline ERDA FY77 [9] & $\begin{array}{l}\text { Economically attractive } \\
\text { Environmentally acceptable }\end{array}$ & $\begin{array}{l}\mathbf{A} \\
\mathbf{B}\end{array}$ & $\begin{array}{l}\mathrm{A} \\
\mathrm{B} \\
\mathrm{n}\end{array}$ & $\begin{array}{l}=1.0 \\
=1.0 \\
=2.0\end{array}$ \\
\hline $\begin{array}{l}\text { National } \\
\text { Energy Plan } \\
\text { [2] }\end{array}$ & $\begin{array}{l}\text { Conservation } \\
\text { Renewable } \\
\text { Conservation } \\
\text { Increase supply } \\
\text { Environment } \\
\text { Intergovernment relations } \\
\text { Citizen participation } \\
\text { Reduce hardship }\end{array}$ & $\begin{array}{c}0.5 \mathrm{~A}, 0.5 \mathrm{~B} \\
0.5 \mathrm{~A}, 0.5 \mathrm{~B} \\
0.5 \mathrm{~A}, 0.5 \mathrm{~B} \\
\mathrm{~A} \\
\mathrm{~B} \\
\mathrm{~S} \\
\mathrm{~S} \\
0.5 \mathrm{~S}, 0.25 \mathrm{E}, 0.25 \mathrm{~A}\end{array}$ & $\begin{array}{l}\mathrm{A} \\
\mathrm{B} \\
\mathrm{S} \\
\mathrm{E} \\
\mathrm{n}\end{array}$ & $\begin{array}{l}=2.75 \\
=2.5 \\
=2.5 \\
=0.25 \\
=8.0\end{array}$ \\
\hline $\begin{array}{l}\text { "U.S. Needs to } \\
\text { Compensate for } \\
\text { Cheap Energy"[6] }\end{array}$ & $\begin{array}{l}\text { Price }=\text { true cost } \\
\text { Cut consumer risk }\end{array}$ & $0.5 C, 0.5 A$ & $\begin{array}{l}\mathrm{A} \\
\mathrm{C} \\
\mathrm{n}\end{array}$ & $\begin{array}{l}=1.5 \\
=\quad 0.5 \\
=2.0\end{array}$ \\
\hline $\begin{array}{l}\text { ERDA FY76: } \\
\text { Tee }{ }^{a}[8]\end{array}$ & $\begin{array}{l}\text { Short-term stability } \\
\text { Long-term growth } \\
\text { Economically competitive } \\
\text { Environmentally acceptable } \\
\text { Economically viable } \\
\text { Reli eve de mand } \\
\text { Positive environmental } \\
\text { aspects } \\
\text { Internalize environmental } \\
\text { costs } \\
\text { Health }\end{array}$ & $\begin{array}{c}0.5 \mathrm{C}, 0.5 \mathrm{~A} \\
\mathrm{~A} \\
\mathrm{~A} \\
\mathrm{~B} \\
\mathrm{~A} \\
\mathrm{~A} \\
\mathrm{~B} \\
\mathrm{~B} \\
\mathrm{~B}\end{array}$ & $\begin{array}{l}\text { A } \\
\text { B } \\
\text { C } \\
n\end{array}$ & $\begin{array}{l}=4.5 \\
=4.0 \\
=\quad 0.5 \\
=\quad 9.0\end{array}$ \\
\hline $\begin{array}{l}\text { ERDA FY76: } \\
\text { HUD }^{\text {b }}[8]\end{array}$ & $\begin{array}{l}\text { Relieve demand } \\
\text { Marketability } \\
\text { Profitability } \\
\text { Economically viable } \\
\text { Technically viable } \\
\text { Stimulate productive } \\
\text { capacity } \\
\text { Market de mand } \\
\text { Stimulate information }\end{array}$ & $\begin{array}{l}\text { A } \\
\text { A } \\
\text { A } \\
\text { A } \\
\text { A } \\
\\
\text { A } \\
\text { A } \\
\text { A }\end{array}$ & $\begin{array}{l}A \\
B \\
S \\
n\end{array}$ & $\begin{array}{l}=9.0 \\
=1.0 \\
=\quad 2.0 \\
\equiv\end{array}$ \\
\hline
\end{tabular}

afrom testimony of Dr. John M. Teem, Acting Assistant Administrator for Solar, Geothermal, and Advanced Energy Systems, ERDA.

b From HUD Program. Plan, on a Solar Heating and Cooling Demonstration Program (residential dwelling). 


\begin{tabular}{|c|c|c|c|c|}
\hline Source & Value Mentioned or Implied & Value Cluster & & Total \\
\hline $\begin{array}{l}\text { ERDA FY76: } \\
\text { HUD } \\
\text { (continued) }\end{array}$ & $\begin{array}{l}\text { Remove institutional } \\
\text { constraints } \\
\text { Remove social constraints } \\
\text { Remove environmental } \\
\text { constraints } \\
\text { Consumer acceptance }\end{array}$ & $\begin{array}{c}0.5 \mathrm{~A}, 0.5 \mathrm{~S} \\
\mathrm{~S} \\
\mathrm{~B} \\
0.5 \mathrm{~S}, 0.5 \mathrm{~A}\end{array}$ & & \\
\hline$\frac{\text { The President's }}{\text { Energy Progra m }}$ & $\begin{array}{l}\text { Sacrifice } \\
\text { Economic growth } \\
\text { Standard of living } \\
\text { Jobs } \\
\text { Protect environment } \\
\text { Reduce vulrierability } \\
\text { Fairness } \\
\text { Reduce de mand } \\
\text { Price = replacement cost } \\
\text { Government predictability } \\
\text { Conserve scarce resources } \\
\text { Develop unconventional } \\
\text {.sources for } 21 \text { st Century }\end{array}$ & $\begin{array}{c}\mathrm{S} \\
\mathrm{A} \\
\mathrm{A} \\
0.5 \mathrm{~A}, 0.5 \mathrm{~S} \\
\mathrm{~B} \\
\mathrm{C} \\
\mathrm{S} \\
\mathrm{A} \\
\mathrm{A} \\
0.5 \mathrm{~S}, 0.5 \mathrm{C} \\
\mathrm{A} \\
\mathrm{S}\end{array}$ & $\begin{array}{l}\text { A } \\
B \\
S \\
C \\
n\end{array}$ & $\begin{array}{l}=5.5 \\
=1.0 \\
=4.0 \\
=1.5 \\
=12.0\end{array}$ \\
\hline$\frac{\frac{\text { Solar Energy }}{\text { Research \& }}}{\text { Development }}$ & $\begin{array}{l}\text { Environment } \\
\text { Economically competitive } \\
\text { Energy self-sufficiency } \\
\text { Political independence } \\
\text { Availability } \\
\text { Benign } \\
\text { Inexhaustible } \\
\text { Economically competitive } \\
\text { Environmentally acceptable } \\
\text { Early as possible }\end{array}$ & $\begin{array}{l}\text { B } \\
\text { A } \\
\text { C } \\
\text { C } \\
\text { C } \\
\text { B. } \\
\text { A } \\
\text { A } \\
\text { B } \\
\text { C }\end{array}$ & $\begin{array}{l}\mathrm{A} \\
\mathrm{B} \\
\mathrm{C} \\
\mathrm{N}\end{array}$ & $\begin{array}{l}=3.0 \\
=3.0 \\
=4.0 \\
=10.0\end{array}$ \\
\hline $\begin{array}{l}\text { Project Inde- } \\
\text { pendence [l] }\end{array}$ & $\begin{array}{l}\text { U.S. self-sufficiency } \\
\text { Environm ental benefit } \\
\text { Less climatic effect } \\
\text { Export technology }\end{array}$ & $\begin{array}{l}\text { C } \\
\text { B } \\
\text { B } \\
\text { A }\end{array}$ & $\begin{array}{l}\mathrm{A} \\
\mathrm{B} \\
\mathrm{C} \\
\mathrm{n}\end{array}$ & $\begin{array}{l}=1.0 \\
=2.0 \\
=1.0 \\
=4.0\end{array}$ \\
\hline $\begin{array}{l}\text { Oregon Energy } \\
\text { Office [10] }\end{array}$ & $\begin{array}{l}\text { Permanent } \\
\text { Indigenous } \\
\text { Safe } \\
\text { Reliable } \\
\text { Mass production } \\
\text { Gradual technical } \\
\text { integration } \\
\text { Abundant } \\
\text { No secrecy or security } \\
\text { problems } \\
\text { No irreversible ecosystem } \\
\text { change } \\
\text { No irreversible social } \\
\text { change }\end{array}$ & $\begin{array}{c}\text { S } \\
\text { C.5 } 0.5 \mathrm{E} \\
\mathrm{C} \\
\mathrm{A} \\
\underset{\mathrm{C}}{0.5 \mathrm{~A}, 0.5 \mathrm{~S}} \\
\mathrm{~A} \\
\mathrm{~S} \\
\mathrm{~B} \\
\mathrm{~S}\end{array}$ & $\begin{array}{l}\text { A } \\
\text { B } \\
\text { S } \\
\text { C } \\
\text { E } \\
\mathrm{n}\end{array}$ & $\begin{array}{l}=2.5 \\
=1.0 \\
=3.5 \\
=2.5 \\
=0.5 \\
=10.0\end{array}$ \\
\hline
\end{tabular}




\begin{tabular}{llcc}
\hline Source & Value Mentioned or Implied & Value Cluster & \multicolumn{2}{c}{ Total } \\
\hline National Solar & Increase resources & $\cdots$ & $\mathrm{A}=3.5$ \\
Energy Day & Conserve nonrenewables & $0.5 \mathrm{~A}, 0.5 \mathrm{~B}$ & $\mathrm{~B}=1.5$ \\
Resolution & Nonpolluting & $\mathrm{B}$ & $\mathrm{S}=0.5$ \\
{$[10]$} & Inexhaustible & $\mathrm{A}$ & $\mathrm{E}=0.5$ \\
& Benefit to all mankind & $0.5 \mathrm{~S}, 0.5 \mathrm{E}$ & $\mathrm{n}=6.0$ \\
& Through private industry & $\mathrm{A}$ & \\
\hline
\end{tabular}

Selected Members of Congress, Senate* [10]

\begin{tabular}{|c|c|c|c|c|}
\hline Source & Value Mentioned or Implied & Value Cluster & & Total \\
\hline A & $\begin{array}{l}\text { Free } \\
\text { Clean } \\
\text { Inexhaustible } \\
\text { Simple } \\
\text { Benign }\end{array}$ & $\begin{array}{l}\text { A } \\
\text { B } \\
\text { A } \\
\text { S } \\
\text { B }\end{array}$ & $\begin{array}{l}\text { A } \\
B \\
\text { S } \\
n\end{array}$ & $\begin{array}{l}=2.0 \\
=\quad 2.0 \\
=\quad 1.0 \\
=5.0\end{array}$ \\
\hline B & Small business & $0.5 \mathrm{~A}, 0.5 \mathrm{~S}$ & $\begin{array}{l}A \\
S \\
n\end{array}$ & $\begin{array}{l}=0.5 \\
=\quad 0.5 \\
=\quad 1.0\end{array}$ \\
\hline $\mathbf{C}$ & Long-ter $\mathrm{m}$ crisis avoidance & $\mathrm{C}$ & $\frac{C}{n}$ & $\begin{array}{l}=1.0 \\
=1.0\end{array}$ \\
\hline D & $\begin{array}{l}\text { Balance supply and demand } \\
\text { National independence } \\
\text { National security } \\
\text { Prosperity } \\
\text { National welf are } \\
\text { Competition } \\
\text { Small business }\end{array}$ & $\begin{array}{c}\mathrm{A} \\
\mathrm{C} \\
\mathrm{C} \\
\mathrm{A} \\
\mathrm{S} \\
\mathrm{A} \\
0.5 \mathrm{~A}, 0.5 \mathrm{~S}\end{array}$ & $\begin{array}{l}A \\
S \\
C \\
n\end{array}$ & $\begin{array}{l}=3.5 \\
=1.5 \\
=\quad 2.0 \\
=7.0\end{array}$ \\
\hline $\mathbf{E}$ & $\begin{array}{l}\text { Balance nuclear and } \\
\text { nonnuclear: diversity } \\
\text { Guarantee supply } \\
\text { Reduce reliance } \\
\text { World social responsibility } \\
\text { Reduce balance-of-trade } \\
\text { problem }\end{array}$ & $\begin{array}{c}0.5 \mathrm{~A}, 0.25 \mathrm{~S}, 0.25 \mathrm{C} \\
C \\
\mathrm{C} \\
0.5 \mathrm{C}, 0.25 \mathrm{~S}, 0.25 \mathrm{E} \\
0.5 \mathrm{~A}, 0.5 \mathrm{C}\end{array}$ & $\begin{array}{l}\text { A } \\
\mathrm{S} \\
\mathrm{C} \\
\mathrm{E} \\
\mathrm{n}\end{array}$ & $\begin{array}{l}=1.0 \\
=\quad 0.5 \\
=\quad 3.25 \\
=0.25 \\
=\quad 5.0\end{array}$ \\
\hline F & $\begin{array}{l}\text { Small business } \\
\text { Take power from nuclear } \\
\text { and oil industry } \\
\text { Avoid strip mining } \\
\text { Expand alternatives }\end{array}$ & $\begin{array}{c}0.5 \mathrm{~A}, 0.5 \mathrm{~S} \\
\mathrm{~S} \\
\mathrm{~B} \\
0.5 \mathrm{~A}, 0.5 \mathrm{~S}\end{array}$ & $\begin{array}{l}\mathrm{A} \\
\mathrm{B} \\
\mathrm{S} \\
\mathrm{n}\end{array}$ & $\begin{array}{l}=1 \\
=1 \\
=\quad 2 \\
=4\end{array}$ \\
\hline
\end{tabular}

*The six senators (Fannin, Ford, Gravel, Humphrey, McGovern, and McIntyre) are treated collectively as one source. See Table 3-2. 


\section{Seleeted Members of Congress, House of Representatives* [10]}

\begin{tabular}{|c|c|c|c|c|}
\hline Source & Value Mentioned or Implied & Value Cluster & & Total \\
\hline \multirow[t]{2}{*}{$\mathbf{A}$} & $\begin{array}{l}\text { National independence } \\
\text { Stable economy } \\
\text { Healthy ecionomy } \\
\text { Clean environment }\end{array}$ & $\begin{array}{l}\text { C } \\
\text { A } \\
\text { A } \\
\text { B }\end{array}$ & $\begin{array}{l}\text { A } \\
\text { B } \\
\text { S } \\
\text { C }\end{array}$ & $\begin{array}{l}=3.5 \\
=1.5 \\
=\quad 1.0 \\
=\quad 2.0\end{array}$ \\
\hline & $\begin{array}{l}\text { Secure supply } \\
\text { Renewable } \\
\text { Minimum public sacrifice } \\
\text { Cost effective }\end{array}$ & $\begin{array}{c}\mathrm{C} \\
0.5 \mathrm{~A}, 0.5 \mathrm{~B} \\
\mathrm{~S} \\
\mathrm{~A}\end{array}$ & $\bar{n}$ & $=8.0$ \\
\hline $\mathbf{B}$ & $\begin{array}{l}\text { Health } \\
\text { Environment } \\
\text { Economical to industry }\end{array}$ & $\begin{array}{l}\text { B } \\
\text { B } \\
\text { A }\end{array}$ & $\begin{array}{l}\text { A } \\
\mathbf{B} \\
\mathbf{S}\end{array}$ & $\begin{array}{l}=2.5 \\
=\quad 2.0 \\
=\quad 1.5\end{array}$ \\
\hline . & $\begin{array}{l}\text { Economical to workers } \\
\text { Economical to consumers } \\
\text { Revision of priorities }\end{array}$ & $\begin{array}{l}0.75 \mathrm{~A}, 0.25 \mathrm{~S} \\
0.75 \mathrm{~A}, 0.25 \mathrm{~S} \\
\mathrm{~S}\end{array}$ & $\bar{n}$ & $=6.0$ \\
\hline $\mathbf{C}$ & $\begin{array}{l}\text { Third World needs } \\
\text { Third World industriali- } \\
\text { zation }\end{array}$ & $\begin{array}{l}\mathrm{L} \\
\mathrm{A}\end{array}$ & $\begin{array}{l}\mathbf{A} \\
\mathrm{E} \\
\mathrm{n}\end{array}$ & $\begin{array}{l}=1.0 \\
=1.0 \\
=2.0\end{array}$ \\
\hline $\mathrm{D}$ & $\begin{array}{l}\text { Rural development } \\
\text { Decentralization, small- } \\
\text { scale }\end{array}$ & $\begin{array}{l}0.75 \mathrm{~S}, 0.25 \mathrm{~A} \\
0.75 \mathrm{~S}, 0.25 \mathrm{~A}\end{array}$ & $\begin{array}{l}A^{\cdot} \\
\mathrm{S} \\
\mathrm{n}\end{array}$ & $\begin{array}{l}=0.5 \\
=\quad 1.5 \\
=\quad 2.0\end{array}$ \\
\hline $\mathbf{E}$ & $\begin{array}{l}\text { Solve national energy } \\
\text { problem } \\
\text { Employment } \\
\text { Economic }\end{array}$ & $\begin{array}{c}\mathrm{C} \\
0.5 \mathrm{~A}, 0.5 \mathrm{~S} \\
\mathrm{~A}\end{array}$ & $\begin{array}{l}A \\
S \\
C \\
n\end{array}$ & $\begin{array}{l}=1.5 \\
=0.5 \\
=\quad 1.0 \\
=3.0\end{array}$ \\
\hline $\mathbf{F}$ & $\begin{array}{l}\text { Deemphasize breeder, } \\
\text { provide choice }\end{array}$ & $\mathbf{S}$ & $\frac{\mathrm{s}}{\mathrm{n}}$ & $\begin{array}{l}=1.0 \\
=1.0\end{array}$ \\
\hline \multirow[t]{2}{*}{$\mathbf{G}$} & $\begin{array}{l}\text { Bust giant corporations } \\
\text { Lncal }\end{array}$ & $\begin{array}{c}-0.75 \mathrm{~S}, 0.25 \mathrm{~A} \\
\mathrm{~S}\end{array}$ & $\begin{array}{l}\text { A } \\
\mathbf{S}\end{array}$ & $\begin{array}{l}=0.25 \\
-\quad 3.75\end{array}$ \\
\hline & $\begin{array}{l}\text { Decentralized } \\
\text { Needs of local communities }\end{array}$ & $\begin{array}{l}\mathbf{S} \\
\mathbf{S}\end{array}$ & $\mathrm{n}$ & $=4.0$ \\
\hline
\end{tabular}

*The nine Representatives (Abzug, Anderson, Emery, Gude, Koch, Ottinger, Runnels, Thone, and Weaver) are treated collectively as one source. See Table 3-2. 
10

\begin{tabular}{|c|c|c|c|c|}
\hline Source & Value Mentioned or Implied & Value Cluster & & Total \\
\hline $\mathrm{H}$ & $\begin{array}{l}\text { Reduce reliance on OPEC } \\
\text { Reduce environmental } \\
\text { problems } \\
\text { Give us time to make a } \\
\text { choice } \\
\text { Reduce environmental risk }\end{array}$ & $\begin{array}{l}\text { C } \\
\text { B } \\
\text { S } \\
\text { B }\end{array}$ & $\begin{array}{l}B \\
S \\
C \\
n\end{array}$ & $\begin{array}{l}=2.0 \\
=1.0 \\
=\quad 1.0 \\
=4.0\end{array}$ \\
\hline \multirow[t]{2}{*}{ I } & Maintenance free & $\mathrm{C}$ & C & $=1.0$ \\
\hline & & & $\mathrm{n}$ & $=1.0$ \\
\hline
\end{tabular}

Adrocates

\begin{tabular}{|c|c|c|c|c|}
\hline Source & Value Mentioned or Implied & Value Cluster & & Total \\
\hline Daly [9] & $\begin{array}{l}\text { Nondepletable } \\
\text { Nonpolluting } \\
\text { Harm ony with nature } \\
\text { Dispersed: advantages and } \\
\text { disadvantages } \\
\text { Solar income.vs. geological } \\
\text { capital (nondepletable) } \\
\text { Nondepletable, per manent } \\
\text { All of the above instru- } \\
\text { mental toward ethical ends }\end{array}$ & $\begin{array}{c}0.5 \mathrm{~A}, 0.5 \mathrm{~B} \\
\mathrm{~B} \\
\mathrm{~B} \\
\mathrm{~A} \\
\mathrm{~A} \\
0.5 \mathrm{~A}, 0.5 \mathrm{~B} \\
\mathrm{E}\end{array}$ & $\begin{array}{l}A \\
B \\
E \\
n\end{array}$ & $\begin{array}{l}=3.0 \\
=3.0 \\
=1.0 \\
=7.0\end{array}$ \\
\hline $\begin{array}{l}\text { Commoner, } \\
\text { The Poverty of } \\
\text { Power [4] }\end{array}$ & $\begin{array}{l}\text { Renewable: per manent } \\
\text { Eliminate pollution } \\
\text { Reverse cost escalation } \\
\text { Diffuseness: thèrmodynamic } \\
\text { efficiency } \\
\text { Economics } \\
\text { Renewable } \\
\text { Available everywhere } \\
\text { Environmentally benign } \\
\text { Noninflationary } \\
\text { Employment } \\
\text { Non-capital intensive } \\
\text { Avoid environmental } \\
\text { degradation } \\
\text { Community independence } \\
\text { and involvement } \\
\text { Decentralized wealth } \\
\text { Simple technology-diverse } \\
\text { labor } \\
\text { Wide range of policy } \\
\text { options (local, state, } \\
\text { federal) }\end{array}$ & $\begin{array}{c}0.5 \mathrm{~S}, 0.5 \mathrm{~B} \\
\mathrm{~B} \\
\mathrm{~A} \\
\mathrm{~A} \\
\mathrm{~A} \\
0.5 \mathrm{~A}, 0.5 \mathrm{~B} \\
0.5 \mathrm{~A}, 0.5 \mathrm{~S} \\
\mathrm{~B} \\
\mathrm{~A} \\
\mathrm{~A} \\
\mathrm{~A} \\
\mathrm{~B} \\
\mathrm{~S} \\
0.5 \mathrm{~A}, 0.5 \mathrm{~S} \\
\mathrm{~S}\end{array}$ & $\begin{array}{l}A \\
B \\
S \\
n\end{array}$ & $\begin{array}{l}=8.0 \\
=4.0 \\
=4.0 \\
=16.0\end{array}$ \\
\hline
\end{tabular}




\begin{tabular}{|c|c|c|c|c|}
\hline Source & Value Mentioned or Implied & Value Cluster & & Total \\
\hline $\begin{array}{l}\text { Commioner, } \\
\text { Solar Tran- } \\
\text { sition II [6] }\end{array}$ & $\begin{array}{l}\text { Environmental problems } \\
\text { diminished: oil spills } \\
\text { Hazards of both coal } \\
\text { and uranium to } \\
\text { miners and the } \\
\text { general public } \\
\text { Automobile smog } \\
\text { Nuclear radiation } \\
\text { Unsightly and potentially } \\
\text { harmful high-tension } \\
\text { power lines } \\
\text { T.sng-term effects of } \\
\text { carbon dioxide on earth's } \\
\text { heat balance }\end{array}$ & $\begin{array}{l}\text { B } \\
\text { B } \\
\text { B } \\
\text { B } \\
\text { B } \\
\text { B } \\
\text { B }\end{array}$ & $\frac{B}{n}$ & $\begin{array}{l}=7.0 \\
=7.0\end{array}$ \\
\hline $\begin{array}{l}\text { Hayes, } \\
\text { Rays of Hope } \\
{[13]}\end{array}$ & $\begin{array}{l}\text { Efficient } \\
\text { Renewable } \\
\text { Decentralized } \\
\text { Simple } \\
\text { Safe } \\
\text { Flexibility in social } \\
\text { design } \\
\text { Diverse } \\
\text { Dispersed } \\
\text { Social equity } \\
\text { Freedom } \\
\text { Political participation } \\
\text { Limitedness } \\
\text { Conservation } \\
\text { Environmental quality } \\
\text { Employm ent } \\
\text { Decentralization, local } \\
\text { autonomy \& control } \\
\text { Social equity: intra- } \\
\text { national } \\
\text { Social equity: inter- } \\
\text { national } \\
\text { Financial equity: inter- } \\
\text { national } \\
\text { Financial equity: intra- } \\
\text { national }\end{array}$ & $\begin{array}{c}\text { A } \\
0.25 \mathrm{~A}, 0.75 \mathrm{~B} \\
\text { S } \\
0.5 \mathrm{~S}, 0.5 \mathrm{E} \\
\mathrm{C} \\
\mathrm{S} \\
\mathrm{A} \\
\mathrm{S} \\
\mathrm{S} \\
0.5 \mathrm{~S}, 0.5 \mathrm{E} \\
\mathrm{S} \\
\mathrm{B} \\
\mathrm{B} \\
\mathrm{B} \\
\mathrm{A} \\
\mathrm{S} \\
\mathrm{S} \\
\mathrm{S} \\
\mathrm{A} \\
\mathrm{A}\end{array}$ & $\begin{array}{l}\text { A } \\
B \\
S \\
C \\
E \\
n\end{array}$ & $\begin{array}{l}=5.25 \\
=3.75 \\
=9.0 \\
=1.0 \\
=\quad 1.0 \\
=20.0\end{array}$ \\
\hline
\end{tabular}




\begin{tabular}{|c|c|c|c|c|}
\hline Source & Value Mentioned-or Implied & Value Cluster & & Total \\
\hline $\begin{array}{l}\text { Hayes, } \\
\text { Sun Times [14] }\end{array}$ & $\begin{array}{l}\text { Safe } \\
\text { Stable } \\
\text { Sustainable } \\
\text { Self-reliance } \\
\text { Social transformation: } \\
\text { sustainability } \\
\text { Social transformation: } \\
\text { harmony } \\
\text { Social transformation: } \\
\text { justice } \\
\text { Decentralization: social } \\
\text { Decentralization: simplicity } \\
\text { Decentralization: security }\end{array}$ & $\begin{array}{l}\mathrm{C} \\
0.5 \mathrm{~A}, 0.5 \mathrm{~S} \\
\mathrm{~B} \\
\mathrm{~S} \\
\mathrm{~S} \\
\mathrm{~S} \\
\mathrm{~S} \\
\mathrm{~S} \\
0.5 \mathrm{~S}, 0.5 \mathrm{E} \\
\mathrm{C}\end{array}$ & $\begin{array}{l}A \\
B \\
S \\
C \\
E \\
n\end{array}$ & $\begin{array}{ll}= & 0.5 \\
= & 1.0 \\
= & 6.0 \\
= & 2.0 \\
= & 0.5 \\
= & 10.0\end{array}$ \\
\hline Shurcliff [28] & $\begin{array}{l}\text { Cost effectiveness vs. } \\
\text { durability, energy efficiency } \\
\text { Safety }\end{array}$ & $\mathbf{A}$ & $\begin{array}{l}\mathrm{A} \\
\mathrm{S} \\
\mathrm{n}\end{array}$ & $\begin{array}{l}=1.0 \\
=1.0 \\
=2.0\end{array}$ \\
\hline Solar Lobby [2] & $\begin{array}{l}\text { Renewable (used wisely) } \\
\text { Fewer negative environ- } \\
\text { mental consequences } \\
\text { No radioactive waste } \\
\text { No threat of greenhouse effect } \\
\text { Labor intensive } \\
\text { Stable } \\
\text { Resilient } \\
\text { Foster self-reliance } \\
\text { Political and cultural } \\
\text { pluralism } \\
\text { Favorable balance of } \\
\text { payments } \\
\text { Discourage global nuclear } \\
\text { proliferation }\end{array}$ & $\begin{array}{c}\text { E } \\
\text { B } \\
\text { B } \\
0.5 \mathrm{~A}, 0.5 \mathrm{~S} \\
0.5 \mathrm{~A}, 0.5 \mathrm{~S} \\
\mathrm{C} \\
\mathrm{S} \\
\mathrm{S} \\
\mathrm{A} \\
\mathrm{C}\end{array}$ & $\begin{array}{l}\mathrm{A} \\
\mathrm{B} \\
\mathrm{S} \\
\mathrm{C} \\
\mathrm{E} \\
\mathrm{n}\end{array}$ & $\begin{array}{l}=2.0 \\
=\quad 3.0 \\
=\quad 3.0 \\
=\quad 2.0 \\
=\quad 1.0 \\
=11.0\end{array}$ \\
\hline $\begin{array}{l}\text { Self-Reliance } \\
\text { [3] }\end{array}$ & $\begin{array}{l}\text { Major social trans- } \\
\text { formation } \\
\text { Community based } \\
\text { Economio equity } \\
\text { Soft path vs. hard path } \\
\text { Grass roots, low-income } \\
\text { agency involvement } \\
\text { Equity } \\
\text { Small-scale: } \\
\text { decentralized } \\
\text { Small-scale } \\
\text { Affordable } \\
\text { Public input }\end{array}$ & $\begin{array}{c}\text { S } \\
\text { S } \\
\text { A } \\
\text { S } \\
\text { S } \\
0.5 \mathrm{~S}, 0.5 \mathrm{~A} \\
\mathrm{~S} \\
\mathbf{S} \\
\mathrm{A} \\
\mathrm{S}\end{array}$ & $\begin{array}{l}\text { A } \\
\frac{\mathfrak{s}}{n}\end{array}$ & $\begin{array}{l}=2.5 \\
=7.5 \\
=10.0\end{array}$ \\
\hline
\end{tabular}




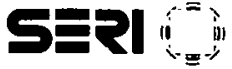

\begin{tabular}{|c|c|c|c|c|}
\hline Source & Value Mentioned or Implied & Value Cluster & & Total \\
\hline Henderson [16] & $\begin{array}{l}\text { Grounded in biological and } \\
\text { ecological reality } \\
\text { Integrated growth vs. } \\
\text { quantitative growth } \\
\text { Renewability: minimum } \\
\text { throughput, sustained } \\
\text { yield, long-term } \\
\text { productivity } \\
\text { Localized, regionalized } \\
\text { efficiency } \\
\text { Satisfying work } \\
\text { Rewarding life-styles } \\
\text { Small business }\end{array}$ & $\begin{array}{c}\mathrm{B} \\
\mathrm{E} \\
\mathrm{A} \\
0.75 \mathrm{~A}, 0.25 \mathrm{~S} \\
\mathrm{E} \\
0.75 \mathrm{~A}, 0.25 \mathrm{~S}\end{array}$ & $\begin{array}{l}A \\
B \\
S \\
\frac{E}{n}\end{array}$ & $\begin{array}{l}=2.5 \\
=\quad 1.0 \\
=\quad 0.5 \\
=\quad 3.0 \\
\equiv \quad 7.0\end{array}$ \\
\hline $\begin{array}{l}\text { Lovins, "How } \\
\text { to Finance the } \\
\text { Energy Tran- } \\
\text { sition" [18] }\end{array}$ & $\begin{array}{l}\text { Economics } \\
\text { Risk } \\
\text { Freedom } \\
\text { Free enterprise } \\
\text { Pluralistic choice } \\
\text { Efficiency: thermodynamic } \\
\text { Diverse } \\
\text { Renewable } \\
\text { Appropriate scale } \\
\text { quality } \\
\text { Cheapness } \\
\text { Safer } \\
\text { Global } \\
\text { Equity } \\
\text { Economics: macro } \\
\text { Jobs } \\
\text { Equity } \\
\text { Equity } \\
\text { Equity: international } \\
\text { National security } \\
\text { Environment: pollution } \\
\text { Economics } \\
\text { Sustainable } \\
\text { Soft (diverse, renewable) } \\
\text { Political control } \\
\text { Decentralization: } \\
\text { antiplanning } \\
\text { Simplicity }\end{array}$ & $\begin{array}{c}\mathrm{A} \\
\mathrm{C} \\
\mathrm{E} \\
\mathrm{A} \\
\mathrm{S} \\
0.5 \mathrm{~A}, 0.5 \mathrm{~B} \\
\mathrm{~A} \\
0.5 \mathrm{~A}, 0.5 \mathrm{~B} \\
\mathrm{~A} \\
\mathrm{~A} \\
\mathrm{C} \\
\mathrm{S} \\
0.5 \mathrm{~A}, 0.5 \mathrm{~S} \\
\mathrm{~A} \\
\mathrm{~A} \\
0.5 \mathrm{~A}, 0.5 \mathrm{~S} \\
0.5 \mathrm{~A}, 0.5 \mathrm{~S} \\
0.5 \mathrm{~A}, 0.5 \mathrm{~S} \\
\mathrm{C} \\
\mathrm{B} \\
\mathrm{A} \\
0.25 \mathrm{~A}, 0.75 \mathrm{~B} \\
0.25 \mathrm{~S}, 0.5 \mathrm{~A}, 0.25 \mathrm{~B} \\
\mathrm{~S} \\
\mathrm{~S} \\
\mathrm{~S}\end{array}$ & $\begin{array}{l}A \\
B \\
S \\
C \\
\frac{E}{n}\end{array}$ & $\begin{array}{l}=11.75 \\
=3.0 \\
=7.25 \\
=3.0 \\
=\frac{1.0}{\equiv} 26.0\end{array}$ \\
\hline
\end{tabular}




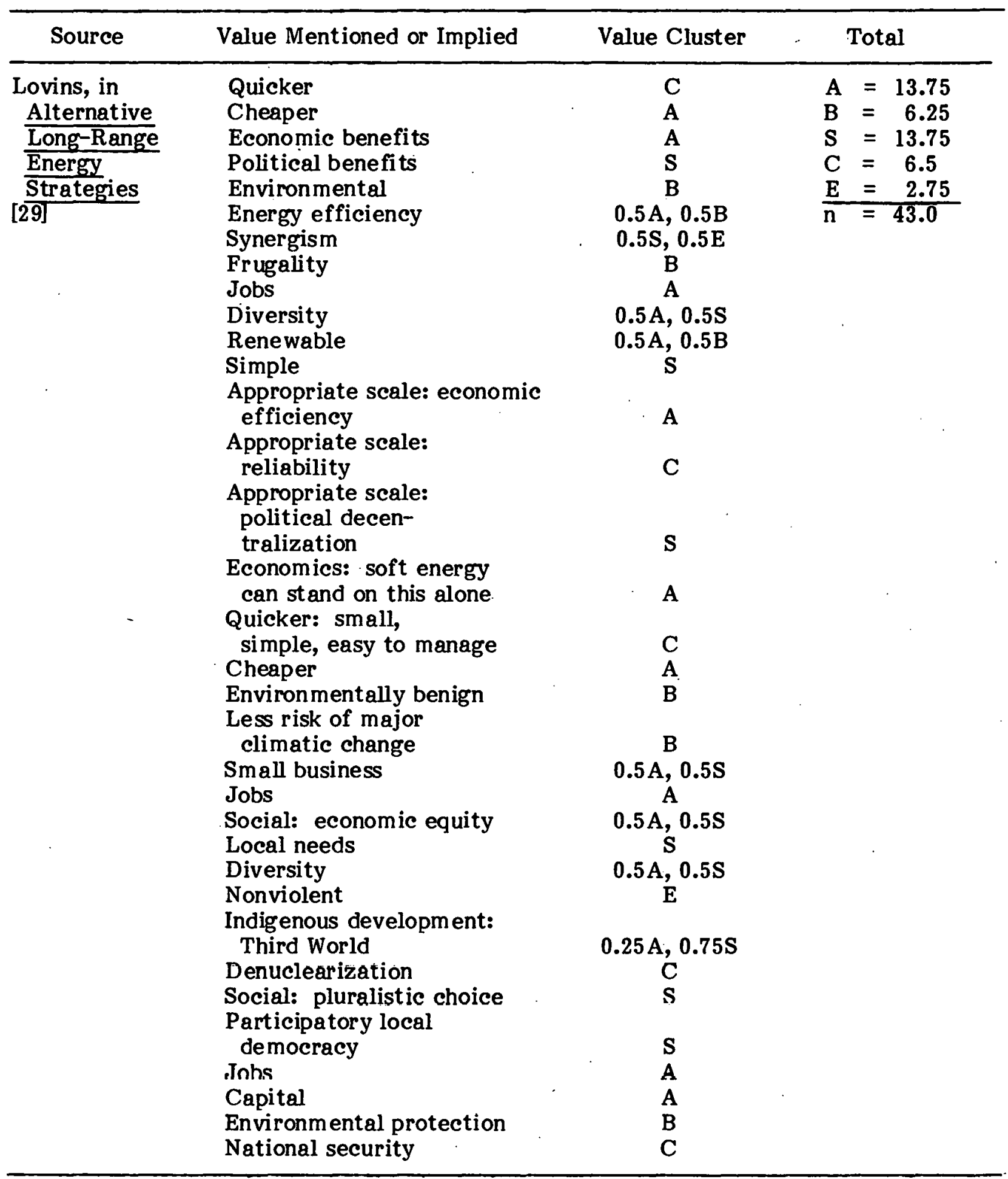




\begin{tabular}{|c|c|c|c|c|c|}
\hline Source & Value Mentioned or Implied & Value Cluster & \multicolumn{3}{|c|}{ Total } \\
\hline $\begin{array}{l}\text { Lovins, } \\
\text { Alternative } \\
\frac{\text { Long-Range }}{\text { Energy }} \\
\text { (Ctrategies } \\
\text { (Continued) }\end{array}$ & $\begin{array}{l}\text { Small business } \\
\text { Spiritual values } \\
\text { Traditional values } \\
\text { Radical reform } \\
\text { World order and equity } \\
\text { Energy independence } \\
\text { Civil rights } \\
\text { States rights } \\
\text { Appropriate energy quality }\end{array}$ & $\begin{array}{c}0.5 \mathrm{~A}, 0.5 \mathrm{~S} \\
\mathrm{E} \\
0.75 \mathrm{~S}, 0.25 \mathrm{E} \\
\mathrm{S} \\
0.25 \mathrm{~A}, 0.25 \mathrm{~S}, 0.5 \mathrm{C} \\
\mathrm{C} \\
\mathrm{S} \\
\mathrm{S} \\
0.75 \mathrm{~A}, 0.25 \mathrm{~B}\end{array}$ & & & \\
\hline New Roots [21] & $\begin{array}{l}\text { Renewability } \\
\text { In-state resour ces } \\
\text { Environment } \\
\text { Conservation: economic } \\
\text { efficiency } \\
\text { Environment } \\
\text { Social impact } \\
\text { Economic cost: } \\
\text { effectiveness } \\
\text { Conservation }\end{array}$ & $\begin{array}{c}\mathrm{B} \\
\mathrm{B} \\
\mathrm{B} \\
\mathrm{A} \\
\mathrm{B} \\
\mathrm{S} \\
\mathrm{A} \\
0.5 \mathrm{~A}, 0.5 \mathrm{~B}\end{array}$ & $\begin{array}{l}\mathrm{A} \\
\mathrm{B} \\
\mathrm{S} \\
\mathrm{n}\end{array}$ & $\begin{array}{l}= \\
\overline{=} \\
=\end{array}$ & $\begin{array}{l}2.5 \\
4.5 \\
1.0 \\
8.0\end{array}$ \\
\hline$\frac{\text { People and }}{\text { Energy }[22]}$ & $\begin{array}{l}\text { Small-scale: dispersed } \\
\text { Jobs } \\
\text { New businesses } \\
\text { Less pollutants } \\
\text { Social benefits } \\
\text { "Nature gives nothing } \\
\text { away free; everything has } \\
\text { a price" }\end{array}$ & $\begin{array}{l}\text { S } \\
\text { A } \\
\text { A } \\
\text { B } \\
\text { S }\end{array}$ & $\begin{array}{l}A \\
B \\
S \\
n\end{array}$ & $\begin{array}{l}= \\
= \\
= \\
=\end{array}$ & $\begin{array}{l}2.0 \\
2.0 \\
2.0 \\
6.0\end{array}$ \\
\hline Reece [26] & $\begin{array}{l}\text { Simple } \\
\text { Accessible to small } \\
\text { business } \\
\text { Low cost }\end{array}$ & $\begin{array}{c}S \\
\underset{A}{0.5 A, 0.5 S}\end{array}$ & $\begin{array}{r}\text { A } \\
-\frac{S}{n}\end{array}$ & $\begin{array}{l}= \\
= \\
=\end{array}$ & $\begin{array}{l}1.5 \\
1.5 \\
3.0\end{array}$ \\
\hline
\end{tabular}




\section{APPENDIX B}

SOCIAL VALUES TAXONOMY OF SOLAR ENERGY: POLICY MAKERS

I. Economic Values

Export technology

Growth

Competition

Decentralization

Risk aversion

Efficiency

Equity

Cost-effectiveness

Growth: limitless

Stability

Renewability

Employment

Balance of trade

Dispersion

Feasibility

Price

Cost

Marketability

Inexhaustibility

Market segmentation

Conservation: fuel efflciency

II. National Security Values

Independence

Nationalism

Reliability

National self-reliance

Control

National self-protection

III. Environmental Values

Cleanness

Inexhaustibility

Safety

Health

Renewability

Conservation 
IV. Social Values

Freedom

Safety

Adaptability

Flexibility

Equity

Social reform

Minimum impact

Simplicity

Citizen participation

Decentralization

Public health

Versatility

Risk reduction

Uncertainty reduction

Psychographic impact

Political impact: decentralization of control over priorities 


\section{APPBNDIX C}

\section{SOCIAL VALUES TAXONOMY OF SOLAR ENERGY: ADVOCATES}

I. Environmental Values

Holistic

Cosmic

Ecological balance

Renewability

Permanence

Sustainability

Harmony

Low resource throughput

Survival of the evolutionary process

Stewardship

Regenerativeness

Thermodynamic efficiency

Organic

Anti-big oil

Anti-nuclear power

Anti-nuclear weapons proliferation

Futur ism

Synergism

No radioactive waste

No greenhouse effect

Environmental improvement

Health

Limits: self-discipline; humility; conservation; perservation; planning; interdependence vs. individualism; responsibility

II. Ethical Values

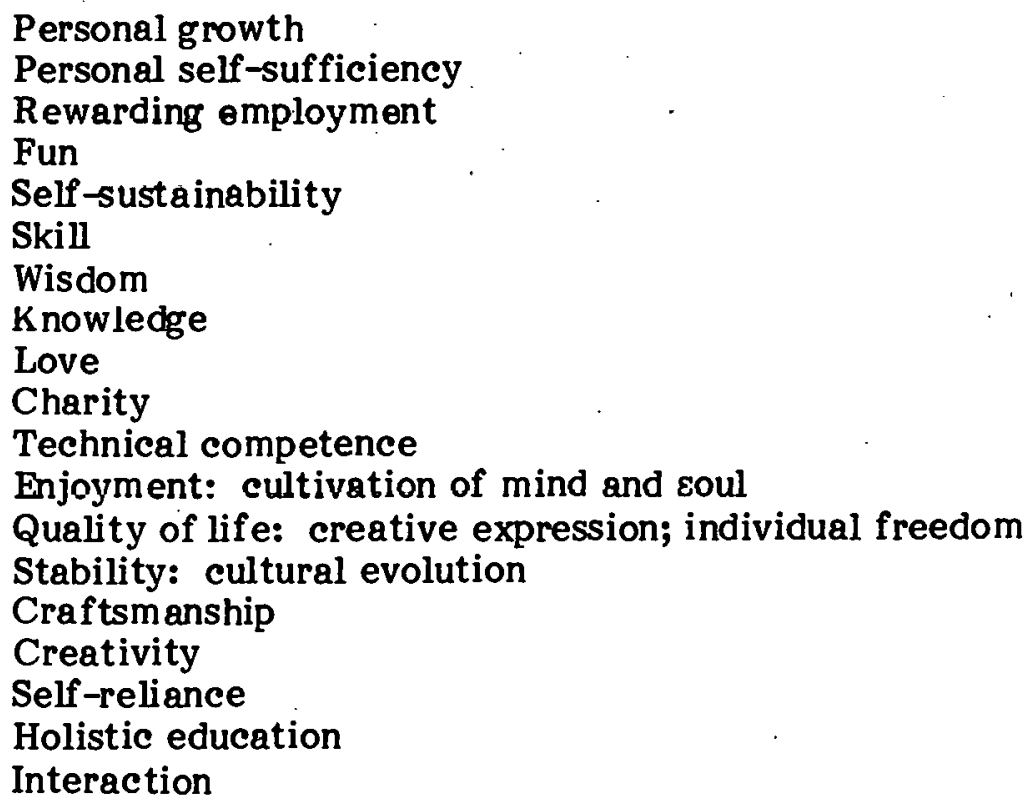


Simplicity: accessibility

Aesthetics

Decentralization: personal freedom

Peace

III. Social Values

Community

Sharing

Local control

Decentralized institutions

Community self-reliance

Smallness

Simplicity

Flexibility

Dispersed

Independence

Demneracy

Diversity

Consumerism

Social justice

Decentralization: freedom; cultural pluralism

Social equity: international; intranational

Heterogeneity

Participatory democracy

Destandardization

Political pluralism

Devolution: decentralized power

Complexity

Safety

Security

National Security:reliability; disarmament; peace; autonomy; economic independence; military independence resiliency security-renewability

Radicalism:

revolutionary transformation; comprehensive review of priorities; large value changes; solar culture vs. solar industry; major change in values, technology, economy; mutual exclusiveness of soft and hard energy paths; harmony; justice; smallness; simplicity; security; conservation

Conservatism: local control; personal self-sufficiency; no free lunch; distrust of government bureaucracy; distrust of taxation; distrust of multinational corporations; small business; family farms; participatory democracy; work ethic; preservation

IV. Economic Values

Economic holism: material sufficiency; durability; thrift; enoughness; small business; simplicity; amenity rights; destandardization; use value vs. exchange value; conviviality; reciprocity; price stability; appropriateness 
Efficiency: cheapness; pragmatism; appropriateness; affordability; competition; capacity not greater than need; net energy; capital requirements; decentralization; internalizing externalities

Equity: $\quad$ full employment; full employment-hard core unemployed; international equity; intranational equity; labor intensive; economic democracy

Growth: new businesses; new foreign markets; favorable balance of trade; progress vs. momentum

Sustainability: maximum sustainable consumption; stability 
SEPI 


\section{APPENDIX D}

THE PROPORTIONATE PREQUENCY WTTH WHCH POICY MAKRRS AND ADVOCATES ATTRIBUTE VARIOUS VALUES TO SOLAR ENERGY

Table D-1. POLICY MAKER' PROPORTIONATE FREQUENCIES REGARDING VALUE CLUSTERS

\begin{tabular}{|c|c|c|c|c|c|c|}
\hline \multirow{2}{*}{. } & \multicolumn{5}{|c|}{ Value Clusters - \% Frequencies } & \multirow{2}{*}{$\begin{array}{c}\text { Number of } \\
\text { Value } \\
\text { Mentions }\end{array}$} \\
\hline & Economic & Environmental & Social & Security & Ethical & \\
\hline$\frac{\text { Solar Energy Progress }}{\text { and Promise }[4]^{a}}$ & $73 \%$ & $6 \%$ & $13 \%$ & $8 \%$ & - & 12 \\
\hline$\frac{\frac{\text { National Energy Act: }}{\text { Reference Information }}}{[16]}$ & 54 & 8 & 4 & 33 & - & 6 \\
\hline$\frac{\text { National Program Plan }}{[15]}$ & 100 & - & - & - & - & 1 \\
\hline$\frac{\text { Solar Energy: A Status }}{\text { Report }[17]}$ & 44 & 16 & 21 & 19 & - & 1 \\
\hline$\frac{\text { U.S. Energy Dem and }}{\text { and Supply [18] }}$ & 67 & - & - & 33 & - & 6 \\
\hline Solar Energy Policy [7] & 50 & - & 50 & - & - & 1 \\
\hline$\frac{\text { Solar Power from }}{\text { Satellites }[12]}$ & 59 & 18 & 12 & 11 & - & 14 \\
\hline ERDA FY77 [9] & 50 & 50 & - & - & - & 2 \\
\hline National Energy Plan [2] & 34 & 31 & 31 & - & 3 & 8 \\
\hline $\begin{array}{l}\text { "U.S. Needs to Compensat } \\
\text { for Cheap Energy" [6] } \\
\text { ERDA FY76: Teem [8] }\end{array}$ & $\begin{array}{r}75 \\
50\end{array}$ & - & - & $\begin{array}{r}25 \\
6\end{array}$ & - & $\begin{array}{l}2 \\
9\end{array}$ \\
\hline ERDA FY76: HUD [8] ${ }^{c}$ & 75 & 8 & 17 & - & - & 12 \\
\hline$\frac{\text { The President's Energy }}{\text { Program [13] }}$ & 46 & 8 & 33 & 13 & - & 12 \\
\hline$\frac{\text { Solar Energy Research }}{\text { and Development [11] }}$ & 30 & 30 & - & 40 & - & 10 \\
\hline Project Independence [10] & 25 & 50 & - & 25 & - & 4 \\
\hline
\end{tabular}




\section{Table D-1. POLICY MAKERS' PROPORTIONATE FREQUENCIES REgARDING VALUE CLUSTERS (concluded)}

\begin{tabular}{|c|c|c|c|c|c|c|}
\hline \multirow{2}{*}{$\cdot$} & \multicolumn{5}{|c|}{ Value Clusters - $\%$ Frequencies } & \multirow{2}{*}{$\begin{array}{l}\text { Number of } \\
\text { Value } \\
\text { Mentions }\end{array}$} \\
\hline & Economic & Environmental & Social & Security & Ethical & \\
\hline Oregon Energy Office [10] & 25 & 10 & 35 & 25 & 5 & 10 \\
\hline $\begin{array}{l}\text { National Solar Energy Day } \\
\text { Resolution [10] }\end{array}$ & 58 & 25 & 8 & - & 8 & 6 \\
\hline Subtotal ${ }^{d}$ & 55 & 18 & 10 & 14 & 1 & \\
\hline Senate total [10] & 31 & 11 & 25 & 32 & 1 & \\
\hline Housc total [10] & 24 & 11 & 399 & $2 n$ & .3 &. \\
\hline Totale $^{\mathrm{e}}$ & 51 & 17 & 15 & 15 & 1 & \\
\hline
\end{tabular}

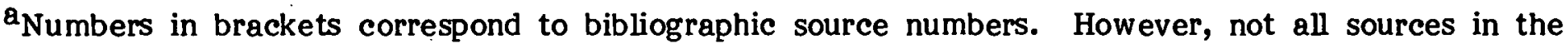
Bibliography are mentioned here because some do not discuss solar energy-related values.

${ }^{b}$ From testimony of Dr. John M. Teem, Acting Assistant Administrator for Solar, Geothermal, and Advanced Energy Systems, ERDA.

CFrom HUD Program Plan on a Solar Heating and Cooling Demonstration Program (residential dwelling).

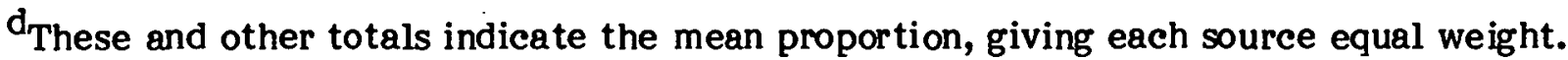

$\mathrm{e}_{\text {This }}$ total is computed in the same way as the others, with the House and Senate counted as separate : sources (see next table). The values listed in this row, then, are the unweighted averages of all sources listed. 
Table D-2. U.S. HOUSE OF REPRESENTATIVES AND U.S. SENATE POLCY MAKERS' PROPORTIONATE FREQUENCIES REGARDING VALUE CLUSTERS

\begin{tabular}{|c|c|c|c|c|c|c|}
\hline & \multicolumn{5}{|c|}{ Value Clusters - $\%$ Frequencies } & \multirow{2}{*}{$\begin{array}{l}\text { Number of } \\
\text { Value } \\
\text { Mentions }\end{array}$} \\
\hline & Economic & Environmental & Social & Security & Ethical & \\
\hline Sen. A & $40 \%$ & $40 \%$ & $20 \%$ & - & - & 5 \\
\hline Sen. B & 50 & - & 50 & - & - & 1 \\
\hline Sen. C & - & - & - & 100 & - & 1 \\
\hline Sen. D & 50 & - & 21 & 29 & - & 7 \\
\hline Sen. $E$ & 20 & - & 10 & 65 & 5 & 5 \\
\hline Sen. F. & 25 & 25 & 50 & - & - & 4 \\
\hline Sen. Total & 30 & 8 & 25 & 35 & 1 & \\
\hline Rep. A & 44 & 19 & 12 & 25 & - & 8 \\
\hline Rep. B & 42 & 33 & 25 & - & - & 8 \\
\hline Rep. C & 50 & - & - & - & 50 & 2 \\
\hline Rep. D & 25 & - & 75 & - & - & 2 \\
\hline Rep. E & 50 & - & 17 & 33 & - & 3 \\
\hline Rep. F & - & - & 100 & - & - & 1 \\
\hline Rep. G & 6 & - & 94 & - & - & 4 \\
\hline Rep. H & - & 50 & 25 & 25 & - & 4 \\
\hline Rep. I & - & - & - & 100 & - & 1 \\
\hline House Total & 24 & 11 & 39. & 20 & 6 & \\
\hline
\end{tabular}

${ }^{a_{H}}$ ouse Committee on Science and Technology 1976. 
SERI 


\section{APPENDIX E \\ THE VALUE HIERARCHIES OF SOME ADVOCATES}

\section{Herman Daly}

Herman Daly, while espousing the idea that environmental and ethical values deserve the highest priority, places the two at opposite ends of a continuum. Ethics (or religion) is the ultimate end, or terminal value. Physics (which determines the laws of nature, particularly the thermodynamic laws so important to energy) is the ultimate means, or instrumental value. Daly believes that the economic concept of trade-offs between values, implied by frequency distributions or other method of weighting values in a proportionate manner, is inappropriate when absolutes are involved. He states, "Economics ... has falsely assumed that ... pluralities, relativities, and substitutabilities among competing ends and scarce means were representative of the whole spectrum (of values). Absolute limits are absent from the economists' paradigm because we encounter absolute limits only in confrontation with ultimates, which have been excluded ..." [9, p. 19). Much of his book details the design of social institutions (which of ten use market mechansims) to help remedy this lack of attention to ultimates.

\section{Barry Commoner}

In The Poverty of Power, Commoner develops the thesis that "logically the economic system ought to conform to the requirements of the production system, and the production system to the requirements of the ecosystem. The governing influence should flow from the ecosystem through the productive system, to the economic system" $[4$, p. 2]. The precedence of environmental over productive and economic values is clear, but the hierarchical place of social values-"the governing influence"-is unclear. Apparently, social values, like economic values, are instrumental toward conforming with environmental conditions. But to identify a value as instrumental is not to downgrade its importance. Commoner devotes a great deal of his attention to the economics of solar energy, believing that solar energy does conform to environmental needs and must be designed to be economical so that it can meet these environmental needs.

\section{Rain Book}

This source conforms to a general belief among advocates that ethical values should come before economic values: "Before we choose our tools and techniques, we must choose our dreams and values."

\section{Amory Lovins}

Lovins also places the values of ethics and the environment before social and economic structure. "Whether we can respond to the energy challenge goes far deeper than our debates on socialism vs. capitalism, or even Jeffersonianism vs. Hamiltonianism. It depends rather on our values toward the earth and toward each other, not necessarily on the outward form of our political institutions. Profit and private enterprises can be fair, planning and nationalization can be inequitable-not to mention inefficient" [18, p. 10]. Lovins thus believes that we must choose a "soft path" of technologies which are diverse 
and renewable. This path is imperative on ethical, social, security, environmental, and economic grounds. He believes that the decision to adopt the soft path can be made within the traditional economic decision-making function, or what he calls a "technological fix." He further argues that the soft path can be adopted with "no significant change in life-style," but places this in sharp contrast to the harsh changes necessary to keep us on the hard, nuclear, and nonrenewable path.

While he seems to find many life-style changes desirable, he identifies these changes as his personal choice. He believes that such personal freedom and choice are among the highest values of the soft path.

\section{New Roots}

An article "Do We Need It at All?" in the grass roots appropriate technology magazine New Roots indicates that ethical consideration (frugality, conservation) must go along with environmental considerations. Renewability as an economic tool is seen as a necessary, though not a sufficient, tool toward achieving appropriateness.

\section{William Shurcliff}

Shurcliff apparently disagrees with some advocates (Lovins, Commoner) on the criteria for economic efficiency. Cost effectiveness, and not necessarily thermodynamic efficiency or durability, should be the criterion for designing, regulating, and adopting solar energy systems. Economic efficiency is not determined entirely by consistency with environmental values; where the two conflict, the former should take precedence, Shurcliff states. He also mentions safety as a value equally important with economic efficiency. 


\section{APPENDIX F \\ BIBLIOGRAPHY: POLICY MAKERS}

1. "Solar Funding Lag Blasted.". Atlanta Journal. 10 January 1979.

2. The National Energy Plan. Cambridge, MA: Ballinger Publishing Company; 1977.

3. National Environmental Policy Act of 1969. Pub. L. 91-190, 1 January 1970, 83 Stat. 852 (Title 42 Sub. Sec. 4321, 4333-4335, 434 1-4347).

4. The President's Council on Environmental Quality. Solar Energy: Progress and Promise. 1978.

5. Sharp, Phillip; Brunner, Ronald. Local Energy Policies. Ann Arbor, MI: Institute of Public Policy Studies, University of Michigan; Discussion Paper No. 127; 1978.

6. "U.S. Needs to Compensate for Cheap Energy." Solar Energy Intelligence Report. 12 February 1979; p. 63.

7. U.S. Community Services Administration. Solar Energy Policy. 1978.

8. U.S. Congress, House Committee on Science and Technology. " ERDA Authorization: Part III, 1976 and Transition Period, Solar Heating and Cooling. Hearings before the Subcommittee on Energy Research, Development, and Demonstration. No. 4,94th Cong., lst Sess., 1975.

9. U.S. Congress, House Committee on Science and Technology. ERDA Authorization Fiscal Year 1977: Part II, Solar Energy. Hearings before the Subcommittee on Energy Research, Development, and Demonstration. No. 72, 94th Cong., 2nd Sess., 1976.

10. U.S. Congress, House Committee on Science and Technology. Solar Energy Legislation through the 94th Congress, Prepared for the Subcommittee on Energy Research, Development, and Demonstration. 94th Cong., 2nd Sess., 1976.

11. U.S. Congress, Joint Committee on Atomic Energy. Solar Energy Research and Development. Hearings before the Joint Committee on Atomic Energy on 5.2819 and 5.3234. 93rd Cong., 2nd Sess., 1974.

12. U.S. Congress, Senate Committee on Aeronautical and Space Sciences. Solar Power from Satellites. Hearings before the Subcommittee on Aerospace Technology and National Needs. 94th Cong., 2nd Sess., 1976.

13. U.S. Congress, Senate Committee on Energy and National Resources. The President's Energy Program: A Compilation of Documents. No. 95-16, 95th Cong., 1st Sess., 1977.

14. Solar Energy Research Institute. Public Meeting on Solar Technology. Washington, DC: U.S. Department of Energy, 1978. 
15. U.S. Dept. of Energy. National Program Plan for Research and Development in Solar Heating and Cooling for Building, Agricultural, and Industrial Applications. 1978.

16. U.S. Dept. of Energy, Office of Public Affairs. The National Energy Act: Reference Information. Washington, DC: U.S. DOE; 1979.

17. U.S. Dept. of Energy. Solar Energy: A Status Report. Washington, DC: U.S. DOE; 1978.

18. U.S. Energy Demand and Supply, 1976-1985: Limited Options, Unlimited Constraints. No. 186; 1978. 


\section{APPENDIX G \\ BIBLIOGRAPHY: SOLAR ADVOCATES}

1. Baldwin, Deborah. "The Problem with Paying More for Less." Environmental Action. pp. 21-23; May 1979.

2. Blueprint for a Solar America. Washington, DC: Solar Lobby; 1979.

3. "Carter's Crash Course on Solar Energy." Self-Reliance. September/October 1978.

4. Commoner, Barry. The Poverty of Power. New York: Alfred A. Knopf, Inc.; 1976.

5. Commoner, Barry. "Reflections: The Solar Transition-I." New Yorker. 23 April 1979; pp. 53-92.

6. Commoner, Barry. "Reflections: The Solar Transition - II." New Yorker. 23 April 1979; pp. 46-93.

7. "Consumer Activists Launching Shadow Energy Department." Wall Street Journal.

8. Crowther, Richard. Interview on KOA-TV, Denver, CO: 28 December 1978.

9. Daly, Herman. Steady-State Economics. San Francisco: W. H. Freeman and Company; 1979.

10. "Leadership for Solar Effort." The Denver Post. 27 February 1979.

11. Hannon, Bruce. "Economic Growth, Energy Use, and Altruism." Alternatives to Growth - I. Dennis L. Meadows, ed. Cambridge, MA: Ballinger Publishing Company; 1977.

12. Hayes, Denis. "The Coming Energy Transition." The Futurist. October 1977; pp. 303-310.

13. Hayes, Denis. Rays of Hope. New York: W.W. Norton Co., Inc.; 1977.

14. Hayes, Denis. "Self-Reliance: The Next Stage." Sun Times. April 1979; p. 7.

15. Henderson, Hazel. Creating Alternative Futures. New York: Berkely Windhover Books; 1978.

16. Henderson, Hazel. "The End of Flat Earth Economics and the Transition to Renewable Resource Societies." Alternatives. Winter 1978; pp. 15-22.

17. Johnson, Lee. "With a Little Help from Our Friends." Rain. August/September 1978.

18. Lovins, Amory. "How to Finance the Energy Transition." Not Man Apart. September/October 1978; p. 8.

19. Mal'iel", Dür. "Bular Survival." Alternative Suurces of Energy. May/June 1979; p. 10 . 
20. McCall, Tom. Does Your Future Have a Future? Commencement Address at Colorado College, Colorado Springs, CO; 4 June 1979.

21. "Do We Need It at All?" New Roots. September/October 1978.

22. People and Energy. "Hazards of Solar Energy." November/December 1978; pp. 5-6:

23. People and Energy. February/March 1978.

24. "The Right-Wing and Appropriate Technology: The Possibilities for Mutual Aid." Rain. January 1978.

25. Rainbook. By the staff of Rain magazine. Shocken Books; 1977.

26. Reece, Ray. "Eclipsing the Solar Inventor." Environmental Action. May 1979; pp. 21-23.

27. Schatz, Joel. "Cosmic Economics." Alternative Sourcès of Energy. July 1975; pp. 25-27.

28. Shurcliff, William. "Regulating Bureaucrats-Not the Sun." Rain. June 1978; p. 8.

29. U.S. Congress, Senate Interior Affairs Committee. Alternative Long-Range Energy Strategies. Ser. no. (94-47), (92-137), 94th Congress, 2nd Sess., 1976. 


\begin{tabular}{|c|c|c|}
\hline $\begin{array}{l}\text { Document Control } \\
\text { Page }\end{array}$ & $\begin{array}{l}\text { 1. SERI Report No. } \\
\text { RR-722-329R }\end{array}$ & 3. Recipient's Accession No: \\
\hline \multicolumn{2}{|l|}{ 4. Title and Subtitle } & $\begin{array}{l}\text { 5. Publication Date } \\
\text { July } 1980\end{array}$ \\
\hline \multicolumn{2}{|c|}{$\begin{array}{l}\text { Social Values and Solar Energy Policy: The Policy } \\
\text { Maker and the Advocate }\end{array}$} & 6. \\
\hline \multicolumn{2}{|c|}{$\begin{array}{l}\text { 7. Author(s) } \\
\text { Avraham Shama: Ken Jacobs }\end{array}$} & 8. Performing Organization Rept. No. \\
\hline \multirow{2}{*}{\multicolumn{2}{|c|}{$\begin{array}{l}\text { 9. Performing Organization Name and Address } \\
\text { Solar Energy Research Institute } \\
1617 \text { Cole Boulevard } \\
\text { Golden, Colorado } 80401\end{array}$}} & $\begin{array}{l}\text { 10. Project/Task/Work Unit No. } \\
5326.40\end{array}$ \\
\hline & & $\begin{array}{l}\text { 11. Contract (C) or Grant (G) No. } \\
\text { (C) } \\
\text { (G) }\end{array}$ \\
\hline \multirow{2}{*}{\multicolumn{2}{|c|}{ 12. Sponsoring Organization Name and Address }} & $\begin{array}{l}\text { 13. Type of Report \& Period Covered } \\
\text { Research Report }\end{array}$ \\
\hline & & 14. \\
\hline
\end{tabular}

15. Supplementary Notes

16. Abstract (Limit: 200 words) Solar energy policy makers and advocates have significantly different hierarchies (clusters) of values upon which they evaluate the adoption of solar technologies. Content analysis, which examines the frequency with which policy makers identify different types of values, indicates that they hold economic values to be of primary importance. Environmental, social, and national security values are also substantial elements of the policy makers' value clusters associated with solar energy. This finding is confirmed by a qualitative analysis of policy makers' values. Advocates, on the other hand, assign almost equal weights ( $33 \%$ ) to economic values and social values, slightly less weight to environmental values, and significant attention to ethical and security values as well. These results of frequency analysis are made somewhat more complicated by a qualitative interpretation of the advocates' positions. As part of their more holistic approach, several of the advocates indicated that all values discussed by them are instrumental toward achieving higher-order, ethical and environmental values. In addition our preliminary investigation indicates that neither group is entirely homogeneous. Testing this and other propositions, as well as obtaining a similar picture of the values which the public associates with solar energy, are topics of future research.

17. Document Analysis

a. Descriptors Solar Energy; Policy; Policy Makers; Legislators; Evaluation; Design; Implementation; Commercialization; Economic; Environment; Ethics; Sociology; Security; Comparative Evaluations; Solar Advocate

b. Identifiers/Open-Ended Terms

c. UC Categories

$58 a$

18. Availability Statement

National Technical Information Service

U.S. Department of Commerce

5285 Port Royal Road

Springfield Vtrginia 22161

19. No. of Pages

69

20. Price 